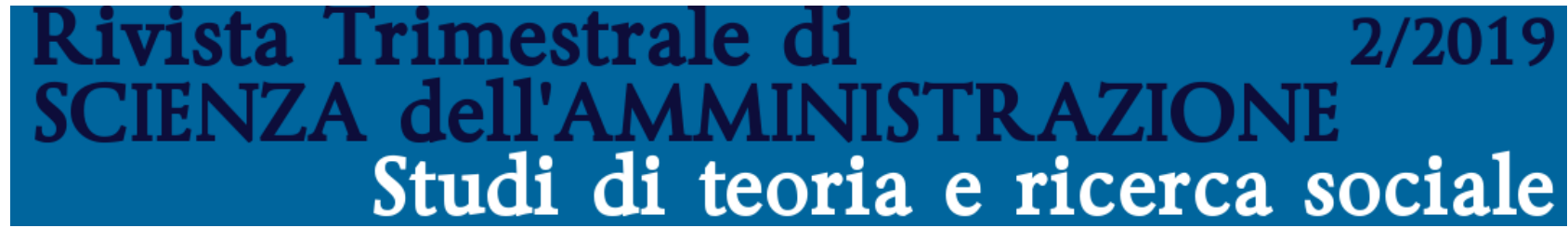

\title{
Political communication in Social Networks Election campaigns and digital data analysis: a bibliographic review ${ }^{1}$
}

\author{
Luca Corchia
}

Università di Pisa

\begin{abstract}
The outcomes of a bibliographic review on political communication, in particular electoral communication in social networks, are presented here. The electoral campaigning are a crucial test to verify the transformations of the media system and of the forms and uses of the linguistic acts by dominant actors in public sphere candidates, parties, journalists and Gatekeepers. The aim is to reconstruct the first elements of an analytical model on the transformations of the political public sphere, with which to systematize the results of the main empirical research carried out in recent years, in particular those conducted with a promising methodology: Digital Trace Data Analysis.
\end{abstract}

Keywords: Public sphere, political communication, election campaigning, Social Networks, big data, bibliographical review

Riassunto. La comunicazione politica nei social network. Campagne elettorali e Digital Trace Data Analysis: una rassegna bibliografica

Sono qui presentati i risultati di una rassegna bibliografica sulla comunicazione politica, in particolare la comunicazione elettorale nei social network. Le campagne elettorali sono un test cruciale per verificare le trasformazioni del sistema mediale e delle forme e degli usi degli atti linguistici da parte degli attori dominanti nella sfera pubblica - candidati, partiti, giornalisti e gatekeepers. L'obiettivo è quello di ricostruire i primi elementi di un modello analitico sulle trasformazioni della sfera pubblica politica, con cui sistematizzare i risultati delle principali ricerche empiriche condotte negli ultimi anni, in particolare quelle condotte con una metodologia promettente: la Digital Trace Data Analysis.

Parole chiave: Sfera pubblica, comunicazione politica, campagna elettorale, social networks, big data, rassegna bibliografica

DOI: 10.32049/RTSA.2019.2.04

\section{Introduction}

The expanding use of Social Networks by political parties, candidates and the public has led to an exponential increase of the scientific literature on the relationship between the political system and new media. These studies include a wide range of disciplines, from political science to sociology, from computer science to law, and of course the field of media research. The attempt to outline a review of the scholars, themes and methodological approaches of this field of study, in order to make a comparison, is therefore highly useful. From my point of view, it is interesting to verify the presence of the structural and functional conditions used in political philosophy and

1 This paper is one of the products of the post-doc fellowship at the MediaLaB - Big Data in Social and Political Research of the University of Pisa, directed by Roberta Bracciale and Massimiliano Andretta. 
sociology to examine the quality of the public sphere, such as inclusiveness, transparency, symmetry and discursiveness. These aspects, for example, are essential in Jürgen Habermas' deliberative conception of democracy and in American scientific literature (see Floridia, 2017).

The aim of this bibliographical reconstruction is to start building an analysis model. I will focus on two aspects: election campaigns and Digital Trace Data Analysis. On the one hand, election campaigning - a key moment of the political struggle on which the public agenda focuses - is one of the most promising areas of investigations into political communication. On the other hand, from a methodological point of view I limit the attention to Digital Trace Data Analysis directly detecting communications on Social Networks. The results from which I gather the information do not derive from other approaches, such as surveys, experiments, interviews and case studies, which are traditionally used to conduct research into political participation. The analysis of digital data traces is becoming dominant in the studies of social networking activities and has been applied to multiple electoral campaigning, at local, regional, national and European levels, and it has led to a revision in the definition of public opinion (Anstead \& O'Loughlin, 2015; Bruns \& Highfield, 2015; Klašnja et al., 2017). More generally, in the last decade the attention of the scientific community towards the relationship between Big data and Social science has greatly increased for one main cause: it allows computational analysis to be conducted no longer on the self-referenced behaviour declared by the actors, but on the actual traced behaviour (Chadwick \& Howard, 2008). Digital Trace Data Analysis is an aspect of an emerging social and cultural technological phenomenon (Boyd \& Crawford, 2012) which, for some, inaugurates the Petabyte Age (Manovich, 2012). For a review of Italian papers on the effects of Big data on social research see Bennato (2015), Boccia Artieri (2014; 2015), Davenport (2015), Agnoli \& Parra Saiani (2016) and Lombi \& Marzulli (2017).

\section{Criteria of the bibliographic research}

This review firstly concerns research conducted on social actors - parties, candidates and audiences. Secondly, while not ignoring the "permanent electoral campaign" (Blumenthal, 
1980), I decided to limit the investigation to studies of electoral moments only, including the media events. This excludes much research on other events that hold the limelight in the media (the renewal of offices, demonstrations, news stories, etc.) and on the habitual use of new media in the routinary activities of parliaments, governments and other political bodies, but also escludes research on political communication in mass media (Cepernich, 2017). Regarding Social Networks, I have considered only Twitter and Facebook because they are "the" public space where the electoral communication takes place. Of course, this choice has excluded a series of studies on visual communications (images and videos), on Instagram (Filimonov et al., 2016; Larsson, 2017) and Youtube (Kercher \& Bachl, 2016). Other limiting criteria have been introduced concerning the selection of sources and the systematic criteria for the identification of the most relevant studies. I am following only partially Andreas Jungherr's model (2016a).

The coding process required three main steps: the selection of database sources, the search by key words and the selection by relevance criteria. Three scientific databases covering different subject areas were used: the Social Science Citation Index (SSCI) for leading peer-reviewed social science journals, the Institute of Electrical and Electronics Engineers (IEEE) Digital Library, and the Association for Computing Machinery (ACM) Digital Library for the literature of computer science studies. In order to include the many titles not present in the databases, I have extended the search by keyword combination to the main scholarly Social Networks: Google Scholar, PhilPapers, Social Science Research Network, ORCID, Academia.edu, ResearchGate, and Mendeley. This has allowed me to expand the survey to include peerreviewed scientific journals, conference proceedings of complete peer-reviewed documents widespread in the computer sciences and increasingly frequent in the social sciences - and monographs and miscellaneous volumes. Boolean research was carried out by combination of key words: "big data” OR "digital trace data” AND "Social Network" OR "social media” OR "Twitter" OR "Facebook", with a series of relevant terms and strings of words: "politics", "political communication”, “elections”, “election campaign”, "party”, “candidate”, and all derivatives in English, French, Spanish, Italian and German. Most of the writings are in English. For the specific methods of consultation, the databases and Scholarly Social Networks required different procedural solutions but with equivalent results. The key word search was conducted in 
the titles, abstracts and key words lists of articles and titles, synopses, and indexes of books. For each source, only documents with an ISSN or ISBN code were examined. Furthermore, I have reduced the results by removing, in addition to the duplicates, the texts that were not relevant to the specific object of the bibliographic review. The result is a list of 500 publications. Finally, for this article, a list of 250 writings has been selected on which to conduct a content analysis. The selection of the most significant studies was made taking into account the recurrences in the bibliographical apparatus of the articles and monographs selected on the basis of formal criteria. This makes it possible to highlight the establishment of a real dialogue community of researchers who, for a decade, have been confronting and sharing themes and methods. After collecting and consulting the most interesting essays on electoral campaigns on Social Networks through the analysis of Digital trace data, I have inductively elaborated a classification of their content following, in addition to temporal (when) and spatial (where) categories, those of imputation (who), themes (what), and purpose (why), in order to build a framework of reference in which to place the texts according to whether they mainly dealt with certain subjects, defined specific topics, and had particular cognitive purposes.

The studies examined concern elections held in 45 countries, from 2008 to 2017.

\section{Data analysis (1): who, where, when?}

The growing spread of Facebook and Twitter has led to an exceptional increase in political information and communications on Social Networks, by candidates, parties and the public, particularly during election campaigns and media events related to the elections. In this review I will not consider the specific characteristics of the networks (see Larsson, 2015; Reimar, 2016).

Many studies show that users are not a homogeneous population. So what was once defined as "mass audience" is fragmented into multiple and differentiated "publics of interest" (Larsson \& Hallvard, 2011; Barberá \& Rivero, 2014). For the purposes of this review, the public includes all users who are politically active on Social Networks during election campaigns, i.e. those who, in that period, sent politically relevant Twitter messages with hashtags or keywords or wrote similar 
Facebook posts, and/or who followed the Twitter or Facebook profiles of political candidates or parties (McKelvey et al., 2014). The public also includes professional journalists and media outlets (Bracciale \& Martella, 2016) whose mediatisation is an important object of study for interpreting the communication of political actors (Splendore \& Rega, 2017). A new media system with its own media logic has been set up (van Dijck \& Poell, 2013; Klinger \& Svensson, 2016; Enli \& Simonsen, 2017). Its structure and functions significantly differ from those of the Habermasian model of the public sphere. In this research, we can only introduce the main differences: fragmentation, disintermediation and post-discursiveness.

Graph 1 shows the growing interest of the scientific community in the subject matter, especially since the 2012 United States presidential elections, which were characterized by DataDriven Networked Campaigning (Stromer-Galley, 2014, 140-170). In the following two years publications peaked; some were by scholars attracted by the new phenomena but who did not continue their research activities. Studies have then stabilized and centralized around a homogeneous group of scholars.

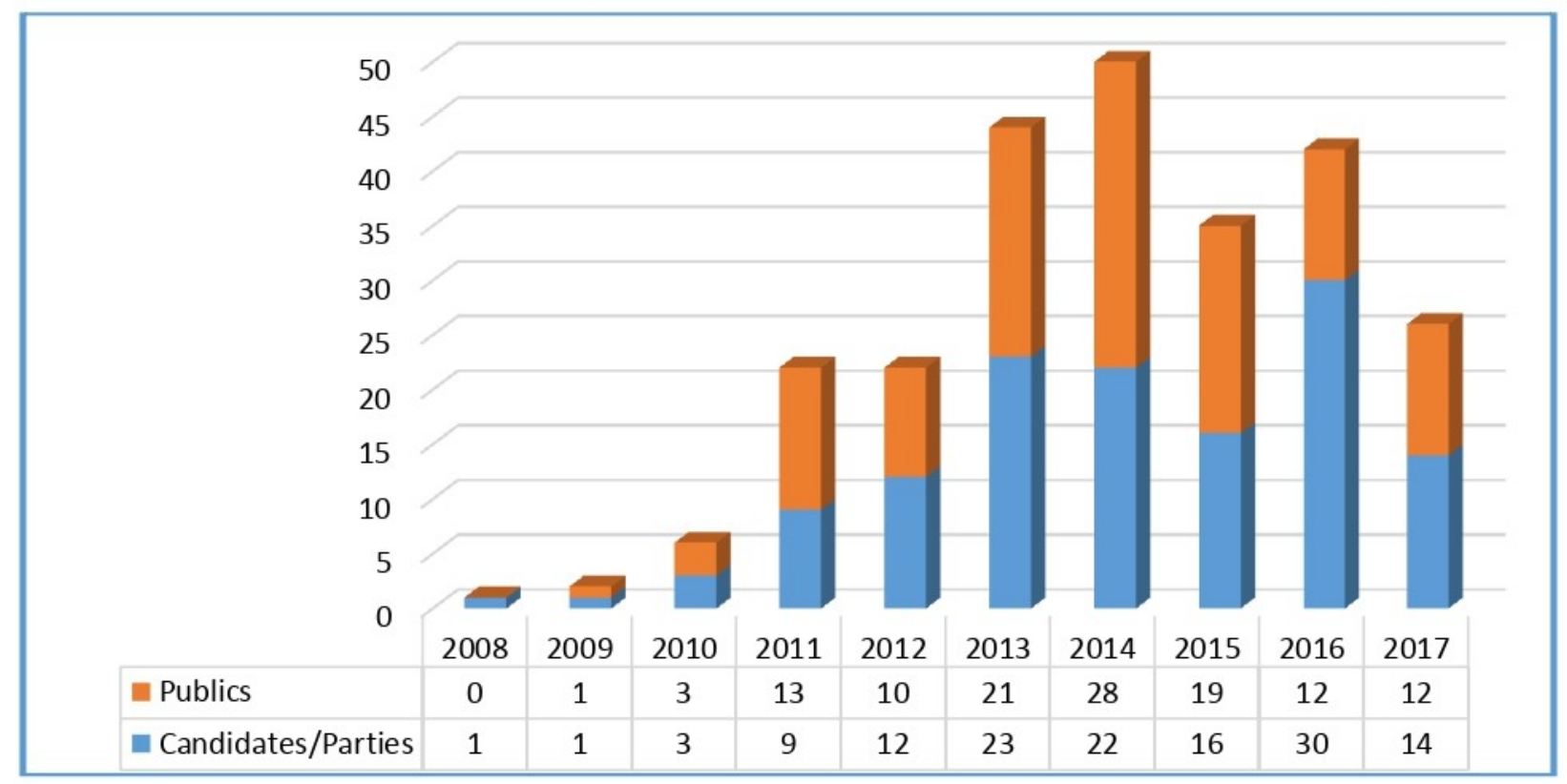

Graph 1. The temporal distribution of researches (2008-2017) 
Table 1 shows the territorial distribution of the researches carried out. As expected, the United States is the country on which most studies focus. However, today there is a considerable amount of literature on the use of Social Networks in election campaigns in many other countries.

\begin{tabular}{|c|c|c|}
\hline Countries & Parties/Candidates & Publics \\
\hline Argentina & Waisbord \& Amado, 2017; & \\
\hline Australia & $\begin{array}{l}\text { Bruns \& Highfield, 2013; Macnamara, 2011; } \\
\text { Macnamara \& Kenning, 2011; Bruns, 2016; } \\
\text { Highfield \& Bruns, 2016; Lukamto \& Carson, } \\
\text { 2016; }\end{array}$ & $\begin{array}{l}\text { Bruns \& Burgess; 2011; Burgess \& Bruns, } \\
\text { 2012; Chen, 2013; Gibson \& McAllister, 2013; } \\
\text { Bruns \& Burgess, 2015; Bruns, 2016; }\end{array}$ \\
\hline Austria & Engesser et al., 2016; & \\
\hline Belgium & D’heer \& Verdegem, 2014; & Harder, 2017; \\
\hline Brazil & Gilmore, 2012; Recuero et al., 2016; & \\
\hline Bulgaria & Seizov, 2015; & \\
\hline Camerun & Ngomba, 2016; & \\
\hline Canada & Small, 2010; Raynauld \& Greenberg, 2014; & $\begin{array}{l}\text { Small, 2011; Elmer, 2012; Raynauld \& } \\
\text { Greenberg, 2014; Small, 2016; }\end{array}$ \\
\hline Chile & Waisbord \& Amado, 2017; & \\
\hline $\begin{array}{l}\text { Czech } \\
\text { Republic }\end{array}$ & Štětka et al., 2014; & \\
\hline Costa Rica & Romero, 2015; & \\
\hline Denmark & $\begin{array}{l}\text { Jensen et al., 2016; Skovsgaard \& Van } \\
\text { Dalen, 2016; Blach-Ørsten et al, 2017; }\end{array}$ & $\begin{array}{l}\text { Larsson \& Moe, 2013; Moe \& Larsson, 2013; } \\
\text { Hussain et al., 2014; }\end{array}$ \\
\hline Ecuador & Waisbord \& Amado, 2017; & \\
\hline Finland & Strandberg, 2013; & Strandberg, 2013; \\
\hline France & Hanna et al., 2013; Papa \& Francony, 2016; & Nooralahzadeh et al., 2013; Ceron et al., 2017; \\
\hline Germany & $\begin{array}{l}\text { Stieglitz et al., 2012; Plotkowiak \& } \\
\text { Stanoevska-Slabeva, 2013; Lietz et al., 2014; } \\
\text { Oelsner \& Heimrich, 2015; Jungherr, 2016b; } \\
\text { Nuernbergk et al., 2016; Nuernbergk \& } \\
\text { Conrad, 2016; }\end{array}$ & $\begin{array}{l}\text { Tumasjan et al., 2010; Feller et al., 2011; } \\
\text { Jürgens et al., 2011; Stieglitz \& Dang-Xuan, } \\
\text { 2012; Tjong Kim Sang \& Bos, 2012; Dang- } \\
\text { Xuan et al., 2013; Jungherr, 2013, 2014; Bleier } \\
\text { at al., 2014; Trilling, 2014; Jürgens \& Jungherr, } \\
\text { 2015; Tsakalidis et al., 2015; Holtz-Bacha \& } \\
\text { Zeh, 2016; Jungherr et al., 2016; Jungherr, } \\
\text { 2017; Quinlan et al., 2017; }\end{array}$ \\
\hline Greece & & Tsakalidis et al., 2015; \\
\hline India & Jaidka \& Ahmed, 2015; Kanungo, 2015; & \\
\hline Indonesia & Amirullah et al., 2013; & \\
\hline Iran & & Sanjari \& Khazraee, 2014; \\
\hline Ireland & Suiter, 2015; & Bermingham \& Smeaton, 2011; \\
\hline $\begin{array}{l}\text { Israel } \\
\end{array}$ & $\begin{array}{l}\text { Haleva-Amir, 2016; Haleva-Amir \& Nahon, } \\
\text { 2016; }\end{array}$ & \\
\hline Italy & $\begin{array}{l}\text { Vaccari \& Valeriani, 2013; Di Fraia et al., } \\
\text { 2014; Bentivegna, 2015; Bentivegna \& } \\
\text { Marchetti, 2015; Paternostro, 2015; Engesser } \\
\text { et al., 2016; Rossi \& Orefice, 2016; } \\
\text { Bracciale \& Martella, 2017a, 2017b; Ceron, } \\
\text { 2016; }\end{array}$ & $\begin{array}{l}\text { Bentivegna, 2014; Cornia, 2014; Ceron \& } \\
\text { d'Adda, 2015; Iannelli \& Giglietto, 2015; } \\
\text { Marchetti \& Ceccobelli 2015; Faggiano, 2016; } \\
\text { Ceron et al., 2017; Splendore \& Rega, 2017; }\end{array}$ \\
\hline
\end{tabular}


Rivista Trimestrale di Scienza dell'Amministrazione - http://www.rtsa.eu - ISSN 0391-190X ISSNe 1972-4942

\begin{tabular}{|c|c|c|}
\hline Japan & Uenohara, 2014; & \\
\hline Kuwait & Miller Noah \& Ko Rosa, 2015; & \\
\hline Malaysia & & Gomez, 2014; \\
\hline México & Waisbord \& Amado, 2017; & \\
\hline Countries & Parties/Candidates & Publics \\
\hline Netherlands & $\begin{array}{l}\text { Voerman \& Boogers 2008; Vergeer et al., } \\
\text { 2011, 2013; Broersma \& Graham, 2012; } \\
\text { Verweij, 2012; Vergeer \& Hermans, 2013; } \\
\text { Graham et al., 2014; Hosch-Dayican et al., } \\
\text { 2014; Kruikemeier, 2014; Van Kessel \& } \\
\text { Castelein, 2016; }\end{array}$ & $\begin{array}{l}\text { Hosch-Dayican et al., 2014; Tsakalidis et al., } \\
\text { 2015; }\end{array}$ \\
\hline New Zealand & Murchison, 2015; & \\
\hline Norway & $\begin{array}{l}\text { Enli \& Skogerbø, 2013; Kalsnes et al., 2014; } \\
\text { Kalsnes, 2016 ; Karlsen \& Enjolras, 2016; } \\
\text { Enli \& Simonsen, 2017; Larsson, 2017; }\end{array}$ & Moe \& Larsson, 2013; \\
\hline Pakistan & Ahmed \& Skoric, 2014; & \\
\hline Philippines & & Pablo et al., 2014; \\
\hline Romania & Pătruţ, 2017; & \\
\hline Russia & & Spaiser et al., 2017; \\
\hline Singapore & & $\begin{array}{l}\text { Skoric et al., 2012; Sreekumar \& Vadrevu, } \\
\text { 2013; }\end{array}$ \\
\hline Slovenia & Deželan et al., 2014; & \\
\hline South Korea & Hsu \& Park, 2012; Park, 2014; & Song et al., 2014; Willnat \& Min, 2016; \\
\hline Spain & $\begin{array}{l}\text { Aragón et al., 2013; López García, 2015; } \\
\text { Ramos-Serrano et al., 2016; Baviera et al., } \\
\text { 2017; Casero-Ripollés et al., 2017; }\end{array}$ & $\begin{array}{l}\text { Barberá \& Rivero, 2014; Borondo et al., 2014; } \\
\text { Calderón-Monge, 2017; }\end{array}$ \\
\hline Sri Lanka & & Rathnayake \& Buente, 2017; \\
\hline Sweden & $\begin{array}{l}\text { Larsson \& Hallvard, 2011; Grussel \& Nord, } \\
\text { 2012; Larsson, 2015; Filimonov et al., 2016; } \\
\text { Larsson \& Moe, 2016; }\end{array}$ & Larsson \& Moe, 2012; Moe \& Larsson, 2013; \\
\hline Switzerland & Klinger, 2013; Engesser et al., 2016; & \\
\hline Taiwan & Lin, 2017; & Cheng \& Chen, 2016; \\
\hline Turkey & $\begin{array}{l}\text { Bayraktutan et al., 2014; İkiz et al., 2014; Polat } \\
\text { \& Özdeşim, 2016; }\end{array}$ & \\
\hline $\begin{array}{l}\text { United } \\
\text { Kingdom }\end{array}$ & $\begin{array}{l}\text { Jackson \& Lilleker, 2009; Anstead \& } \\
\text { O’Loughlin, 2011; Jackson \& Lilleker, 2011; } \\
\text { Baxter \& Marcella, 2012, 2013; Broersma \& } \\
\text { Graham, 2012; Adi et al., 2014; Graham et al., } \\
\text { 2014; Margaretten \& Gaber, 2014; Engesser et } \\
\text { al., 2016; Lilleker et al., 2016; Shephard \& } \\
\text { Quinlan, 2016; }\end{array}$ & $\begin{array}{l}\text { Ampofo et al., 2011; Kim \& Yoo, 2012; } \\
\text { Anstead \& O’Loughlin, 2015; Di Fatta et al, } \\
\text { 2015; Gaber, 2016; Jensen, 2016; }\end{array}$ \\
\hline USA & $\begin{array}{l}\text { Lassen \& Brown, 2010; Shogan, 2010; Chi \& } \\
\text { Yang, 2011; Hong \& Nadler, 2011, 2012; Livne } \\
\text { et al., 2011; Mascaro et al., 2012; Parmelee, } \\
\text { Bichard, 2012; Peterson, 2012; Adams \& } \\
\text { McCorkindale, 2013; Caplan, 2013; } \\
\text { Christensen, 2013; Conway et al., 2013, 2015; } \\
\text { Goodnow, 2013; Hanna et al., 2013; Hemphill } \\
\text { et al., 2013; Hong, 2013; LaMarre \& Suzuki- } \\
\text { Lambrecht, 2013; Mirer \& Bode, 2013; Settle et }\end{array}$ & $\begin{array}{l}\text { Shamma et al., 2009; Diakopoulos \& Shamma, } \\
\text { 2010; Wallsten, 2010; Conover et al., 2011, } \\
\text { 2012; Gayo-Avello, 2011, 2013; Hanna et al., } \\
\text { 2011; Metaxas et al., 2011; Mustafaraj et al., } \\
\text { 2011; Shah \& Yazdani Nia, 2011; Zappavigna } \\
\text { M., 2011; Bond et al., 2012; Parmelee, Bichard, } \\
\text { 2012; Bekafigo \& McBride, 2013; DiGrazia et } \\
\text { al., 2013; Dyagilev \& Yom-Tov, 2013; Groshek } \\
\text { \& Al-Rawi, 2013; Hawthorne et al., 2013; }\end{array}$ \\
\hline
\end{tabular}


al., 2015; Straus et al., 2013; Borah, 2014; Evans et al., 2014; Gainous \& Wagner, 2014; Guo \& Vargo, 2015; Shah et al., 2015; Bruns \& Highfield, 2016; Enli \& Naper, 2016; Evans, 2016; Evans \& Clark, 2016; Kercher \& Bachl, 2016; Kreis, 2016; Lyons \& Veenstra, 2016; Enli, 2017; Evans et al., 2017; McGregor, 2017; Santaniello et al., 2017;
Himelboim, Hansen \& Bowser, 2013; Himelboim, McCreery \& Smith, 2013; Hoang et al., 2013; McKinney et al., 2013; Mejova et al., 2013; Nooralahzadeh et al., 2013; Ackland \& Shorish, 2014; Coddington et al., 2014; Colleoni et al., 2014; Gainous \& Wagner, 2014; Himelboim et al., 2014; Lawrence et al., 2014; Lin et al., 2014; McKelvey et al., 2014; Murthy \& Petto, 2014; Neuman et al., 2014; Vargo et al., 2014; Wayne Xu et al., 2014; Bode et al., 2015; Coffey et al., 2015; Evans \& Clark, 2015; Freelon \& Karpf, 2015; Huberty, 2015; King et al., 2015; MacWilliams, 2015; Meeksm, 2015; Shah et al., 2015; Rowe, 2015; Sudhahar et al., 2015; Xenos et al., 2015; Bessi \& Ferrara, 2016; Just et al., 2016; McGregor \& Mourão, 2016; Reimar, 2016; Shin et al., 2016; Ceron et al., 2017; Cornfield, 2017; Jennings et al., 2017; McGregor \& Mourão, 2017; Ryoo \& Bendle, 2017; Vargo \& Hopp, 2017; Zhang et al., 2017;

Venezuela Waisbord \& Amado, 2017;

Table 1. The distribution by country and object

\section{Data analysis (2): what?}

This review follows Merton's model regarding the specific tasks of sociology: to describe social phenomena, to identify their causes and to explain the relevant consequences. I have examined studies that take into consideration the variables that influence the propensity to use Social Networks during election campaigns (3.1), other studies that focus on the content of the messages, especially the structural form and communicative styles (3.2) and, finally, others that analyse a series of effects produced by the messages on the public and the media system (3.3).

\subsection{Conditions for inclusion and distribution}

Among the studies that examine the tendency to use Twitter or Facebook during election campaigns, the influence of several variables, both ascribed and acquired, was analyzed. In his bibliographic review, Jungherr (2016a) points out the surprising consistency of results in research on electoral cycles in different countries. The most frequent variables are age, gender, 
education, political interest, power, consensus, money, competition, and emulation, etc. More specifically, young politicians make more use of Social Networks and the data is confirmed in the surveys on the public, especially among the young and most educated (Lassen \& Brown, 2010; Jackson \& Lilleker, 2011; Peterson, 2012; Straus et al., 2013; Vergeer \& Hermans, 2013; Uenohara, 2014; Skovsgaard \& Van Dalen, 2016; Blach-Ørsten et al., 2017). There is no unequivocal evidence on the role of gender; some scholars find there to be a greater tendency among male candidates (Gilmore, 2012; Hemphill et al., 2013; Just et al., 2016) while others show a greater presence of women (Jackson \& Lilleker, 2011; Evans et al., 2014). There is, on the other hand, gender bias among users (McGregor \& Mourão, 2016) and specific gender influences on the candidates' communication style and social topics (Evans \& Clark, 2015; 2016). Finally, at a territorial level, it appears that electoral communication on Social Networks is more widely spread in urban districts than in rural ones due to the quantity and density of social ties (Straus et al., 2013).

Social Networks are aimed at those who have a strong interest in politics, which is also expressed in other forms of participation. Opposition parties and candidates appear to use Social Networks more intensively than governmental ones in election campaigns (Lassen \& Brown, 2010; Shogan, 2010; Vergeer et al., 2011; Peterson, 2012; Conway et al., 2013; Hemphill et al., 2013; Plotkowiak \& Stanoevska-Slabeva, 2013; Vergeer \& Hermans, 2013; Ahmed \& Skoric, 2014; Jaidka \& Ahmed, 2015). Supporters of government parties appear to use them less intensively (Conover et al., 2012; Straus et al., 2013).

If we consider the difference between the parties (and candidates) of larger parties that have already been represented for some time in the parliamentary arc and the smaller, recently formed parties, it appears that the former also hold a dominant position in the new media (Vergeer et al., 2011; Gilmore, 2012; Amirullah et al., 2013; Vergeer \& Hermans, 2013; Evans et al., 2014; Raynauld \& Greenberg, 2014). There is a correlation between the tendency to use Social Networks and electoral expenditure (Gilmore, 2012; Peterson, 2012; Quinlan et al., 2017).

Moreover, their use increases with the intensification of electoral competition (Settle et al., 2015; Vergeer \& Hermans, 2013; Evans et al., 2014). Various studies in several countries show that the volume of messages fluctuates strongly and tends to increase towards the end of a 
campaign (Bruns \& Burgess; 2011; Larsson \& Moe, 2012, 2013; Aragón et al., 2013; Bruns \& Highfield, 2013; Hanna et al., 2013; Jungherr, 2013, 2014; Vergeer et al., 2013; Ahmed \& Skoric, 2014; Bentivegna, 2014; Lietz et al., 2014; Jürgens \& Jungherr; 2015; Shah et al., 2015).

Of considerable relevance is the link between electoral communication and major events covered by traditional media, such as leaders' television debates, party assemblies, talk shows, “concession speech” or news items of general interest (Diakopoulos \& Shamma, 2010; Anstead \& O’Loughlin, 2011; Bruns \& Burgess, 2011; Jürgens et al., 2011; Elmer, 2012; Jungherr et al., 2012, 2013; Larsson \& Moe, 2012, 2013; Bruns \& Highfield, 2013; Hanna et al., 2013; Jungherr, 2013, 2014; McKinney et al., 2013; Mirer \& Bode, 2013; Vergeer et al, 2013; Bentivegna, 2014; Graham et al., 2014; Lietz et al., 2014; Kalsnes et al., 2014; Sanjari et Khazraee, 2014; Štětkaet et al., 2014; Vargo et al., 2014; Conway et al., 2015; Jungherr et al., 2016). In particular, messages peak at crucial moments such as when the public flocks to Social Networks for comments (Bentivegna \& Marchetti, 2014; Lin et al., 2014), often, with evaluative, oppositional, ironic-denigrating or conspiracist readings and context considerations, with collective negotiations of meanings (Shamma et al, 2009; Ampofo et al., 2011; Anstead \& O’Loughlin, 2011; Elmer, 2012; Haw-thorne et al., 2013; Jungherr, 2014; Kalsnes et al., 2014; Kreiss, Meadows \& Remensperger, 2014; Trillng, 2014; Coffey et al., 2015; Freelon \& Karpf, 2015; Rowe, 2015; Jennings et al., 2017; Pătruţ, 2017). A central position is held by other politicians and journalists, linked in communication networks (D’heer \& Verdegem, 2014; Lawrence et al., 2014; Enli \& Simonsen, 2017), whose comments focus on the attention of the public and introduce interpretative keys (Bleier et al., 2014; Lin et al., 2014). Their link confirms the high interconnection between traditional media and Social Networks (Chen, 2013; Himelboim, Hansen \& Bowser, 2013; Bentivegna, 2014; Borondo et al., 2014; Sanjari \& Khazraee, 2014).

Ideological polarization appears to favour greater use of Social Networks (Conover et al., 2011; Peterson, 2012; Hanna et al., 2013; Straus et al., 2013; King et al., 2015; Ramos-Serrano et al., 2016; Polat \& Özdeşim, 2016) and more easily activates positions on competing political orientations (Bekafigo \& McBride, 2013; Barberá \& Rivero, 2014). Interesting is the attempt to define standardised measures of political polarization for users and hashtags through the construction of specific algorithms (Hemphill et al., 2016). Some scholars point out a kind of 
emulation factor, in the case of electoral successes, wrongly or rightly attributed to the use of new media by other candidates - copycat hypothesis (Chi \& Yang, 2011; Deželan et al., 2014). Others point to a decisive factor in the spread of electoral communication on Social Networks, i.e.: politicians may not practice it, but citizens will do so against them (Romero, 2015). Finally, there is a rationalization of the way digital tools are used by collaborators and consultants of candidates and parties (Jungherr, 2016b; Kreiss, 2016).

\subsection{The communicative style}

How do parties, candidates and the public use Social Networks during election campaigns? This question concerns the structure, functions, and content of political communication on Twitter and Facebook. Scholars addressed formal aspects (multimedia and hypertextual elements), rhetorical characteristics, pragmatic intentionality (how language is used) and semantic plots (the themes). The composition of these formal and content elements is condensed into different ideal-typical models of "styles" of political communication (Pels, 2012; Moffitt \& Tormey, 2014; Bracciale, Martella, 2017a, 2017b). Also, in this field of study research was carried out in different countries and electoral cycles, obtaining very similar results.

A first dimension concerns the formal structure of messages: the presence of links, images (photos, cartoons, infographics, etc.), videos, Screen-shots (Interactivity Style), and the use of their own functions (shares, retweets, likes, emoticons, etc.). I am less interested in that.

A second dimension regards the use of communication: referential, conversational, and expressive. In Habermas' theory of communicative action (1984; see Corchia, 2010), linguistic acts differ according to whether the dominant attitude is objective about something in the world, relational about other social actors or emotional about subjective experiences. It is an analytical model that could be operationalized in research. It should be pointed out, however, that these are heuristic distinctions. Empirical studies show that generalizations are inappropriate and the use of Social Networks varies greatly among users (Small, 2010; Jackson \& Lilleker, 2011; Macnamara, 2011; Baxter \& Marcella; 2012, 2013; Aragón et al, 2013; Bruns \& Highfield, 2013; Vaccari \& Valeriani, 2013; Vergeer et al., 2013; Adi et al., 2014; Ahmed \& Skoric, 2014; 
Margaretten \& Gaber, 2014; Raynauld \& Greenberg, 2014; Jaidka \& Ahmed, 2015).

Referential use is related to: a) information on something related to politics, policies, news facts, personal aspects of oneself or other actors, etc. (“Informing”); b) and/or "Position taking” on the same matters; c) information about online and offline activities (Self-promotion), in particular: d) institutional interventions (updates on parliamentary work and such like); e) electoral events (“Campaign Updating”); f) support information to other actors (“Endorsement”). In such situations, candidates and parties - more so for the area of government - tend to adopt a "broadcasting” style on Social Networks with informative messages, and less of a conversational style (Shogan, 2010; Small, 2010; Jackson \& Lilleker, 2011; Macnamara; 2011; Baxter \& Marcella, 2012, 2013; Grindel \& Nord, 2012; Adams \& McCorkindale, 2013; Aragón et al, 2013; Enli \& Skogerbø, 2013; Hemphill et al., 2013; Klinger; 2013; Ahmed \& Skoric, 2014; Evans et al., 2014; Graham et al., 2014; İkiz et al., 2014; Kruikemeier; 2014; Jaidka \& Ahmed, 2015; Bentivegna \& Marchetti, 2015; Suiter, 2015). Semantic models of Network Agenda Setting have also been proposed to reconstruct the issue ownership networks of candidates on Social Networks (Guo \& Vargo, 2015). Also relevant are certainly the studies on the factchecking of their statements and, particularly, on the "correctness" of journalistic information and media outlets, which practice more reporting than critical analysis (Coddington et al., 2014).

Conversational use refers to all forms of interaction with and between the public (“Interacting”), with which one: a) argues (“Discuss”); b) declares (“Announcement”); c) engages with announcements and promises (“Commissives”); d) asks for something ("Requesting input”); e) requires a mobilization (“Call to vote” or "call to action”); f) carries out negotiations (“Bargaining”); g) engages in polemics (“Critiquing”); and h) makes irony ("Humor"). Research has shown that candidates and opposition parties tend to use Social Networks more interactively (Jackson \& Lilleker, 2011; Bruns \& Highfield, 2013; Ahmed \& Skoric, 2014), although relations - with significant exceptions (Graham et al, 2014) - involve above all other politicians, in particular those of the same party or coalition (Livne et al., 2011; Hsu \& Park, 2012; Plotkowiak \& StanoevskaSlabeva, 2013), journalists or influencers (Verweij, 2012; Ahmed \& Skoric, 2014; D’heer \& Verdegem, 2014). There is no particular evidence of dialogue between politicians and citizens. In general, the discursive messages are quite a 
minority (Graham et al., 2014; Ngomba, 2016). Explicit requests for mobilization and fundraising are rare (Ahmed \& Skoric, 2014; Evans et al., 2014; Hemphill et al., 2013; Klinger, 2013; Izkiz et al., 2014; Jaidka \& Ahmed, 2015). Considering the number of political messages from the public, only a minority of users is responsible for most of these messages during the elections, while the majority is not posting much (Mustafaraj et al., 2011; Mascaro et al., 2012; Bruns \& Highfield, 2013; Mejova et al., 2013; Barberá \& Rivero, 2014; Jürgens \& Jungherr, 2015; Larsson \& Moe, 2016). This gives the central actors in the networks a crucial importance in the circulation of information and in proposing the interpretative key of the contents (Jürgens et al., 2011; Sudhahar et al., 2015; Jensen et al., 2016). The relevance of humour and satire (Mejova et al., 2013; Sreekumar \& Vadrevu, 2013; Trilling, 2014; Freelon \& Karpf, 2015; Haleva-Amir \& Nahon, 2016; Shin et al, 2016), makes plausible the image of Social Networks as media environments for phatic statements in response to events, rather than deliberative spaces for dialogues on topics and values (Hussain et al., 2014; Holtz-Bacha \& Zeh, 2016). Other studies have shown that interaction is challenging for political parties and there are certain disadvantages in communication with online voters (Kalsnes, 2016).

Expressive use has been considered in the context of the increasing relief of emotions in political communication (“Emotionalization”). This concerns both candidates and voters, among whom negative emotions (indignation, anger, etc.) prevail over positive ones (joy, hope, etc.). Emotions are detected through sentiment analysis (Diakopoulos \& Shamma, 2010; Kim \& Yoo, 2012; Nooralahzadeh et al., 2013; Dang-Xuan et al., 2013; Hoang et al., 2013; Murthy \& Petto, 2014; Di Fatta et al., 2015; Bavaria et al., 2017; Calderón-Monge, 2017). It is not surprising that iconic gestures and images are often viral (Nuernbergk et al., 2016), as well as narratives that facilitate the emotional involvement of an "affective public" (Papacharissi, 2014) attentive to recognize the claims of authenticity, as components of a possible reconstruction of political trust (Margaretten \& Gaber, 2014). Many studies, as we will see, indicate the formation of "filter bubbles" (Pariser, 2011) or "emotional echo chambers" (Himelboim et al., 2014), in which users interact with "like-minded" others, exposing themselves to messages of similar valence.

A third dimension concerns the rhetorical figures of messages. The researchers examined, above all, the communicative form most in tune with the popular culture of the "common 
people” (Popularisation). "Pop politics" (Mazzoleni \& Sfardini, 2009) is characterized by: informality of language ("Informal"); thematic simplification ("Simplification"); narration ("Storytelling”), instrumentalisation of facts (“Instrumental actualisation”), "Dramatisation”, provocations ("Taboo breaker"), trivial lexicon ("Vulgarism”) and negative emotionality ("Negative affect"). Research confirms that most public comments tend to have negative emotional tones (Diakopoulos \& Shamma, 2010; Dang-Xuan et al., 2013; Jungherr, 2013; Mejova et al, 2013; Gainous \& Wagner, 2014; Hosch-Dayican et al., 2014; Park, 2014; Trilling, 2014; Ceron \& d'Adda, 2015; Xenos et al., 2015; Haleva-Amir \& Nahon, 2016; Rossi \& Orefice, 2016; Bracciale \& Martella, 2017a). There are also correlations between levels of partisanship and negative campaigns and the dominant position of candidates in the electoral arena (Evans et al., 2017).

The fourth dimension of content is related to the meanings, that is, what we are talking about (topic) and what is said about it (comment). From the semantic analysis of political communication in Social Networks, corroborated by the inductive reconstructions of topic modeling, we can systematize into five basic categories of political discourse the emerging series of themes.

Political issues (relations between parties or candidates, ideological questions) are selfreferential or positioning interventions (Positioning) in the electoral campaign, the declarations of values of belonging to a political culture, institutional questions of "palace", the confrontation with other candidates and parties, references to plots within the party or line-up (Livne et al., 2011; İkiz et al., 2014) and the role of the leader (Bentivegna \& Marchetti, 2015; Ceron, 2016). Comments on the competition of candidates by political actors and the public are very important (Groshek \& Al-Rawi, 2013; Jungherr, 2014).

Policy issues (general themes, education, health, rights, labour, etc.) constitute a significant part of political communication (Shah \& Yazdani Nia, 2011; Parmelee \& Bichard, 2012; Nooralahzadeh et al., 2013; Cornia, 2014). In electoral campaigns, messages on policies tend to contract with respect to the volume of ordinary periods (Nuernbergk \& Conrad, 2016), ending up condensing into a sort of marketplace of keywords (Cornfield, 2017) that is reconstructed by scholars with topic modeling (Song et al., 2014; Ryoo \& Bendle, 2017). 
With the expression "campaign issues" the literature refers to campaign themes or to events, such as rallies and public meetings, that are frequent on Social Networks (Small, 2010; Macnamara, 2011; Graham et al., 2013; Evans et al., 2014; Graham et al., 2014; Hosch-Dayican et al., 2014).

News or current affairs - more or less political news items, such as terrorist attacks, cataclysms, sports events, art shows, etc. - often fall under the label of “Infotainment” (Bavaria et al., 2017).

Personal issues are contents about personal aspects of candidates, analyzed by literature in the two dimensions of "Personalization", and draw their profiles, beyond the role of delegates, trustees, parties or constituency services (Jackson \& Lilleker, 2009): a) “Individualization”: references to professional qualities and their commitment, with which politicians define themselves (Self-definition); and b) "Privatization": aspects of biography and private, family, and sentimental life, friendships, leisure time, etc.. Studies show that candidates often use Social Networks to highlight strictly personal content (Voerman \& Boogers 2008; Hermans \& Vergeer, 2012; Enli \& Skogerbø, 2013; Goodnow, 2013; Evans et al., 2014; Kruikemeier, 2014; Bentivegna \& Marchetti, 2015; Evans, 2016; Haleva-Amir \& Nahon, 2016; Karlsen \& Enjolras, 2016; Bracciale \& Martella, 2017a; McGregor, 2017).

\subsection{The effects of Social Networks}

The effects of communication via Social Networks on election campaigns are particularly controversial. At the moment, the analyses carried out using big data do not seem to offer exhaustive answers and research carried out through surveys, interviews and experiments is still used. Although it is widely thought that Social Networks have a decisive influence on election campaigns, there seems to be no clear evidence that the use of Twitter and Facebook leads to success in elections. Some scholars identify correlations (Livne et al., 2011; LaMarre \& SuzukiLambrecht, 2013; Gomez, 2014; Lin, 2017) but most scholars deny them (Vergeer et al., 2011; Strandberg, 2013; Huberty, 2015; Miller Noah \& Ko Rosa, 2015; Murthy, 2015; Prémont \& Millette, 2015; McGregor et al., 2017). Similarly, scholars are divided on the link between the 
popularity of candidates and political parties on Social Networks and electoral victory. For some the correlation exists (Gilmore, 2012; DiGrazia et al., 2013; Kruikemeier, 2014; McKelvey et al., 2014), but for others there is no correlation whatsoever (Jungherr, 2013; Mejova et al., 2013; Murthy \& Petto, 2014; Shephard \& Quinlan, 2016). It is not obvious that a positive attitude towards a candidate/political party automatically turns into voting intentions, although some scholars have found correlations between: a) positive feelings and electoral preferences (Tumasjan et al., 2010); b) the presence of a candidate/political party on Social Networks and the number of comments about them; c) the use of Social Networks, political activism and voter turnout (Gaber, 2016). Other scholars have underlined the importance of overlapping online contacts and "real” relationships ("re-intermediation") (Bond et al., 2012).

Lower down the scale, another question concerns the ability of electoral communication on Social Networks to generate political "influence" - a concept not yet unambiguously codified (Dubois \& Gaffney, 2014). Scientific literature has identified several dimensions regarding the indirect relationship between the use of and popularity on Twitter and Facebook and electoral success: a) listening; b) forum; c) interaction; d) mobilization; e) agenda setting; f) framing and priming. This is related to the fact that, in the information circuit in today's hybrid media ecosystem (Chadwick, 2010, 2013; Jungherr, 2014; Chadwick et al., 2016; Harder, 2017), the presence in Social Networks produces more exposure in traditional media (television, radio, press, agencies, etc.), which are a phenomenal driver in determining the appearance of an actor or theme in the Trending Topics lists (Iannelli \& Giglietto, 2015; Marchetti \& Ceccobelli, 2015, Recuero et al., 2016).

The listening effects concern the use of Social Networks in order to obtain opinions and, in general, information about public opinion. Politicians and journalists often tend to use online communication data as an indicator from which to draw impressions or even measures about the climate of opinion in the electorate, not least about themselves (Stieglitz et al., 2012; Lyons \& Veenstra, 2016; Skovsgaard \& Van Dalen, 2016). Against this simplification, scholars note that users should not be considered representative of public opinion (Barberá \& Rivero, 2014; Highfield \& Bruns, 2016; Ceron et al., 2017). This is all the more so if we consider the problem of the "homophilia" of networks composed of interested groups and a priori in favour of 
candidates or parties (Plotkowiak \& Stanoevska-Slabeva, 2013; Ackland \& Shorish, 2014; Trilling, 2014; Jungherr, 2015; Jungherr et al., 2016; Klašnja et al., 2017).

A similar situation was found for interaction effects (Parmelee \& Bichard, 2012). In order to detect the influence in the election campaign, several scholars have adopted the volume of contacts as a metric, with reference to which, in addition to the greater activism of nontraditional actors (Stieglitz \& Dang-Xuan, 2012; Christensen, 2013; Dang-Xuan et al, 2013; Sreekumar \& Vadrevu, 2013; Bentivegna, 2014; Sanjari \& Khazraee, 2014; Freelon \& Karpf, 2015; Jürgens \& Jungherr, 2015), it has been confirmed that users (candidates and public) interact mostly within closed networks, held tight by predefined political affiliations - following their protagonists and sharing their messages - and creating common practices and rituals (Conover et al, 2011, 2012; Feller et al., 2011; Mustafaraj et al., 2011; Bruns \& Highfield, 2013; Himelboim, McCreery \& Smith, 2013; Hoang et al., 2013; Himelboim et al., 2014; Highfield \& Bruns, 2016). On Twitter, for example, supporters of the different parts tend to group around different hashtags, thus creating politically separate communication spaces (Hanna et al., 2011, 2013; Lietz et al., 2014). Leveraging the aggregative effect of the hashtags, there is no lack of incursions of adverse factions into the discursive plots (Conover et al., 2011; Bode et al., 2015; Bruns \& Burgess, 2015; Cheng \& Chen, 2016; Spaiser et al., 2017) - sometimes produced through automated systems (“bots”) (Bessi \& Ferrara, 2016; Rathnayake \& Buente, 2017). There is a trend towards the balkanization of political interaction, whereby users - fragmented into enclaves or echo chambers - «listen to echoes stronger than their voice» (Sunstein, 2007, 13; Garrett \& Kelly, 2009) and opinions are reaffirmed (confirmation bias) in self-referential information circuits (Aragón et al., 2013; Colleoni et al., 2014; Gainous \& Wagner, 2014; Vargo et al., 2014).

Twitter and, to a lesser extent, Facebook are increasingly present in the electoral campaigns of candidates and parties as a tool to "transmit" their messages, mainly in a top-down way (Jackson \& Lilleker, 2011; Peterson, 2012; Adams \& McCorkindale, 2013; Amirullah et al., 2013; Vergeer \& Hermans, 2013; Di Fraia et al., 2014; Gainous \& Wagner, 2014; Pablo et al., 2014; Enli \& Naper, 2016; Lukamto \& Carson, 2016). There is a general effect of “amplifying” political propaganda (Zhang et al., 2017). Interesting is the case study of populist leaders who 
use Social Networks with the same vertical logic of traditional mass media (Waisbord \& Amado, 2017). With regard to the use of the "tribune effect", several scholars have adopted the number of messages as a metric to detect influence in public discourse, partly by finding a correlation with changes in opinion polls that measure the favorable impressions of politicians (Hong \& Nadler, 2011). The results are discordant regarding the distinction between traditional candidates and parties and new political forces. Some scholars consider traditional actors to be prominent (Larsson \& Moe, 2012) while others find non-traditional ones to be prominent (Small, 2011; Mascaro et al., 2012; Larsson \& Moe, 2013). There is a greater propagation of emotional messages (Kim \& Yoo, 2012).

Appeals to the mobilization of candidates and parties and the widening of participation during election campaigns seem confirmed by some studies (Strömbäck \& Nord, 2014; Papa \& Francony, 2016) - although online interactions that are not based on offline networks are weaker in mobilizing participation in the "real world" (Bekafigo \& McBride, 2013; Gibson \& McAllister, 2013; McKelvey et al., 2014; Miller Noah \& Ko Rosa, 2015). In addition, there is evidence that presence and communication on Social Networks contribute to the growth of the collection of electoral funding (Haleva-Amir, 2016), although it seems differentiated between moderate and radical candidates (Hong, 2013; Small, 2016).

An important aspect is the "agenda-setting effect". Social Networks are increasingly present in election campaigns as a tool to influence the coverage and salience of topics in traditional media. Some scholars have noted the specific “attentional dynamics” of traditional media and Social Networks (Neuman et al., 2014; Enli, 2017). Moreover, given the tendency of journalists and media outlets to use messages on Twitter and Facebook as sources, this allows the political class to maintain centrality in the public sphere (Broersma \& Graham, 2012; Verweij, 2012; Spain, Borondo et al., 2014; Conway et al., 2015). In the broader context of disintermediation, political communication is also dependent on a few users of the public - the new Gatekeepers (Jürgens et al., 2011; Vaccari \& Valeriani, 2013; Bentivegna, 2014, 2015; Wayne Xu et al., 2014). These are central to the structure of the network, politically identifiable and have a strong and selective influence in the salience of information shared online and, vice versa, on the virality of radio and television content in social media (Wallsten, 2010). Recently, some studies have focused on the 
active role that the public plays in the choice of different media agendas and in the composition of topics, news and attributes (Vargo et al., 2014; Cheng \& Chen, 2016). There has been a process of "agenda melding” (Shaw \& Weaver, 2014). An interrelated aspect concerns the influence of celebrities, such as those from show business and sport, in starting and directing political debate, particularly during election campaigning, with posts and tweets monolithically appreciated and shared by fan communities (Iannelli \& Splendore, 2017). Another known phenomenon is the "framing" effect, i.e. the interpretative framework with which actors, objects and events are contextualized to favour the attribution of certain meanings rather than others (Borah, 2011). Among the many studies, we mention Parmelee \& Bichard (2012) and Groshek \& Al-Rawi (2013).

An innovative dimension in electoral campaign studies concerns the priming effect, i.e. a heuristic recognition that, by leveraging our long-term unconscious mnemonic system (Schacter, 1992), stimulates familiarity and a rapid and precise identifiability of candidates and parties through the repetition frequency of their profile and messages (Perloff, 2013; Marquis, 2016). The question of the cognitive and evaluative effectiveness of this form of "solicitation" in political communication on Social Networks is found in the literature under the label of the "third level" of the agenda setting (Guo \& McCombs, 2016).

Inquiries suggest that the search for the effects of listening, forum, mobilization, agenda setting, framing and priming is accentuated in aggressive election campaigns (insurgency campaigns), particularly by anti-establishment parties and candidates (Jackson \& Lilleker, 2011; Christensen, 2013; Jungherr, 2013; Bentivegna, 2014; Borah, 2014; Jürgens \& Jungherr, 2015; Kanungo, 2015). A central phenomenon has become the consensus towards movements with populist ideologies and communicative styles, both on the right and on the left, characterized by the rhetoric of "we against them", the emphasis on the will of the people, the imaginary representation of homogeneous communities, the direct contact with ordinary people, forms of direct democracy, the attack against elites (economic, institutional, media and intellectual), the hostility towards "others" and charismatic leadership (Engesser et al., 2016; Van Kessel \& Castelein, 2016; Bracciale \& Martella, 2017; Casero-Ripollés et al., 2017; Santaniello et al., 2017). 
It should be pointed out that many candidates have a presence in Social Networks but use them only rarely. They mark their presence for symbolic aims: as proof of being in step with the zeitgeist, rhetorically inside the new politics - interactive, transparent and in direct contact with people (Grussel \& Nord, 2012; Enli \& Skogerbø, 2013; Nilsson \& Carlsson, 2014; Nuernbergk et al., 2016).

Finally, it is interesting to address the Habermas' question (2006): does Social Networks' electoral communication have the effect of structuring a political public sphere with epistemic values? In other words, does it increase cultural and social capital and produce new models of empowerment? (Jensen, 2016; Willnat \& Min, 2016). In general, the literature has ascertained that candidates and political parties do not use Social Networks to build the conditions for a deliberative democracy and citizens, for their part, contribute much less to improving the argumentative dialogue (Trilling, 2014). Nevertheless, Twitter and Facebook have become an integrated and enduring element of political communication, and we will have to learn how to use them better.

\section{Methodological remarks}

Although the digital data trace analysis on the use of Social Networks in election campaigns is relatively recent, fairly homogeneous results have been obtained over a decade in different election cycles and countries. It is not just for the amount and variety of information and the speed of access to and treatment of it that big data research is becoming widespread among scientists working on the borderline between social sciences and information technology. In conclusion, in the wake of Jungherr's considerations (2016a), we point out some methodological aspects that could help advance these studies.

From the point of view of research design, a better knowledge of existing studies would facilitate a more systematic approach to the research objects and to the operationalization of concepts and properties in variables and indicators. The definition of a shared framework, or at least a greater transparency on the methodologies, is a condition for the improvement of methods, in order to detect the same objects of analysis and to corroborate the same research 
hypotheses (Karpf, 2012).

At the operational level, scholars should explain the procedures for collection and analysis. This is in order to achieve a standardisation of research and, therefore, a greater reliability of techniques and tools. The bibliographic reconstruction has revealed two interesting aspects about how Digital Trace Data Analysis works. First, the automatic collection of Big data contained in profiles, pages, messages, Feed, Hashtag, etc. is available through two approaches: 1) relying on scripts developed by researchers who query the API (application programming interfaces) of Twitter or Facebook or scraping Twitter and Facebook's Web site; ; 2) using third-party software to collect data on these Social Networks. Many studies in the review did not specify how they collected their data, making it difficult for any attempt to replicate and monitor the results and to ascertain how the choice of modalities affects the construction of data sets. Secondly, data collection depends on the criteria for selecting profiles, pages and messages, for example for users, keywords, Hashtags, @Mentions. The choice of one or more of these approaches as well as the predefinition of the specific terms are not indifferent in the construction of the data. These methodological decisions influence the identification of the users who will be included in the study and the relevance of the collected data to the research object. In this regard, there are still no comparative studies to systematically verify whether, how and to what extent the different selection criteria can produce significantly different data sets and, therefore, incomparable research results.

Another limit is the excessive interest in Twitter and, to a lesser extent on Facebook, compared to other Social Networks: Instagram, Youtube, Google+, LinkedIn, Pinterest, Myspace, Orkut, Tumblr and others. Therefore, there are different audiences and other forms of communication that still require adequate scientific attention even in relation to election campaigning.

Another aspect to be explored is the interdependence between different research methods. In the study of Social Networks each one of those has its own strengths and weaknesses (Giglietto et al., 2012). Therefore, in recent years, the promising combination of Digital Trace Data Analysis and Social Network Analysis has become established (Howison et., 2011; Livne et al.. 2011; Conover et al., 2012; Plotkowiak \& Stanoevska-Slabeva, 2013; Lietz et al., 2014; Vargo et al.. 2014; Sudhahar et al., 2015; Pavan \& Caiani, 2017). Triangulation with quantitative 
(surveys and experiments) and qualitative (interviews, content analysis, participating observations, etc.) approaches is also important, in order to extend the fields of application and research hypotheses on behaviour during elections (Song et al., 2014; Wells \& Thorson, 2017).

Finally, in the study of election campaigns, there is an attempt to combine the big data extracted from Social Networks and the micro-data on traditional socio-demographic categories taken from the Census (Vargo \& Hopp, 2017). About the aim of studies: most are descriptions of Social Network activities and explanations of the relationships between particular variables. There are few attempts to develop predictive models of electoral results, starting from the metrics on political activities (Tumasjan et al, 2010; Livne et al., 2011; Gayo-Avello, 2011, 2013; Jungherr, 2011, 2015; MacWilliams, 2015) and the relation between these big data and the opinion polls trends (Tsakalidis et al., 2015; Jungherr et al., 2017).

Ultimately, over a decade the Digital Trace Data Analysis applied to election campaigns on Social Networks has produced a quantity of information previously difficult to find and qualitatively more refined. Further developments will be facilitated by greater comparability of data collection and selection procedures, extended fields of application, integration with Social Network analysis and other traditional research methods, and the development of predictive models of political behaviour. This could foster the emergence of a computational social science in the context of an academic environment open to collaboration, avoiding the risk feared by David Lazer, Albert-László Barabási et al., (2009) that this extraordinary tool for understanding individuals and collectives could become the exclusive competence of private companies and government agencies.

\section{Reference List}

Ackland R., Shorish J. (2014). Political Homophily on the Web. In Cantijoch M., Gibson R., Ward S., eds., Analyzing Social Media Data and Web Networks: New Methods for Political Science. Basingstoke: Palgrave Macmillan.

Adams A., McCorkindale T. (2013). Dialogue and transparency: A content analysis of how the 2012 
Rivista Trimestrale di Scienza dell'Amministrazione - http://www.rtsa.eu - ISSN 0391-190X ISSNe 1972-4942

presidential candidates used Twitter. Public Relations Review, 39, 4: 357. DOI: 10.1016/j.pubrev.2013.07.016.

Adi A., Erickson K., Lilleker D.G. (2014). Elite Tweets: Analyzing the Twitter communication patterns of labour party peers in the House of Lords. Policy \& Internet, 6, 1: 1. DOI: 10.1002/19442866.POI350.

Agnoli M.S., Parra Saiani P., eds. (2016). Sulle tracce dei Big data. Questioni di metodo e percorsi di ricerca. Sociologia e ricerca sociale, special issue, 109.

Ahmed S., Skoric M.M. (2014). My name is Khan: The use of Twitter in the campaign for 2013 Pakistan general election. In Sprague R.H. Jr., ed., HICSS 2014: Proceedings of the 47th Hawaii International Conference on System Science. Washington, DC: IEEE Computer Society. DOI: 10.1109/HICSS.2014.282.

Amirullah F., Komp S., Nurhadryani Y. (2013). Campaign 2.0: An analysis of the utilization social network sites of political parties in Indonesia. In ICACSIS 2013. International Conference on Advanced Computer Science and Information Systems. Washington, DC: IEEE Computer Society. DOI: 10.1109/ICACSIS.2013.6761583.

Ampofo L., Anstead N., O’Loughlin B. (2011). Trust, confidence, and credibility: Citizen Responses on Twitter to opinion polls during the 2010 UK general election. Information, Communication \& Society, 14, 6: 850. DOI: 10.1080/1369118X.2011.587882.

Anstead N., O’Loughlin B. (2011). The emerging viewertariat and BBC question time: Television debate and real-time commenting online. The International Journal of Press/Politics, 16, 4: 440. DOI: $10.1177 / 1940161211415519$.

Anstead N., O’Loughlin B. (2015). Social Media Analysis and Public Opinion: The 2010 UK General Election. Journal of Computer-Mediated Communication, 20: 204. DOI: 10.1111/jcc4.12102.

Aragón P., Kappler K. E., Kaltenbrunner A., Laniado D., Volkovich Y. (2013). Communication dynamics in Twitter during political campaigns: The case of the 2011 Spanish national election. Policy \& Internet, 5, 2: 183. DOI: 10.1002/1944-2866.POI327.

Barberá P., Rivero G. (2014). Understanding the political representativeness of Twitter users. Social Science Computer Review, 33, 6: 712. DOI: 10.1177/0894439314558836.

Baviera T., Peris À., Cano-Orón L. (2017). Political candidates in infotainment programmes and their 
Rivista Trimestrale di Scienza dell'Amministrazione - http://www.rtsa.eu - ISSN 0391-190X ISSNe 1972-4942

emotional effects on Twitter: an analysis of the 2015 Spanish general elections pre-campaign season. Contemporary Social Science: 1. DOI: 10.1080/21582041.2017.1367833.

Baxter G., Marcella R. (2012). Does Scotland "like" this? Social media use by political parties and candidates in Scotland during the 2010 UK general election campaign. Libri, 62, 2: 109. DOI: 10.1515/libri-2012-0008.

Baxter G., Marcella R. (2013). Do online election campaigns sway the vote? A Study of the 2011 Scottish parliamentary election. Libri, 63, 3: 190. DOI: 10.1515/libri-2013-0015.

Bayraktutan G., Binark M., Çomu T., Doğu B., Ǐslamoğlu G., Telli Aydemir A. (2014). 10 The Use of Facebook by Political Parties and Leaders in the 2011 Turkish General Elections. In Pătruţ B., Pătruţ M., eds., Social Media in Politics: Case Studies on the Political Power of Social Media. New York: Springer.

Bekafigo M.A., McBride A. (2013). Who Tweets About Politics? Political Participation of Twitter Users during the 2011 Gubernatorial Elections. Social Science Computer Review, 31, 5: 625. DOI: 10.1177/0894439313490405.

Bennato D. (2015). Il computer come macroscopio. Big data e approccio computazionale per comprendere i cambiamenti sociali e culturali. Milano: FrancoAngeli.

Bentivegna S. (2014). Beppe Grillo’s dramatic incursion into the Twittersphere: Talking politics in 140 characters. Contemporary Italian Politics, 6, 1: 73. DOI: 10.1080/23248823.2014.884377.

Bentivegna S. (2015). A colpi di tweet. La politica in prima persona. Bologna: il Mulino.

Bentivegna S., Marchetti R. (2014) Prove tecniche di ibridazione mediale. Guardare la Tv e commentare su Twitter. Comunicazione politica, 14, 1: 61. DOI: 10.3270/76588.

Bentivegna S., Marchetti R. (2015). Fra tradizione e innovazione. Le elezioni europee del 2014 su Twitter. Comunicazione politica, 15, 3: 389. DOI: 10.3270/81693.

Bermingham A., Smeaton A. (2011). On Using Twitter to Monitor Political Sentiment and Predict Election Results. Workshop on Sentiment Analysis where AI meets Psychology, Chiang Mai, Thailand, 13.11.2011. Available at: https://pdfs.semanticscholar.org/6183/70557dd6c5c4d9399dc2c5286f367f5a7cb6.pdf (26/06/2019).

Bessi A., Ferrara E. (2016). Social bots distort the 2016 U.S. Presidential election online discussion. First Monday, 21, 11: 1. 
Blach-Ørsten M., Kæmsgaard Eberholst M., Burkal R. (2017). From hybrid media system to hybridmedia politicians: Danish politicians and their cross-media presence in the 2015 national election campaign, Journal of Information Technology \& Politics, 14, 4: 334. DOI: 10.1080/19331681.2017.1369917.

Bleier A., Blumenberg M., Gummer T., Hussain A., Kaczmirek L., Kinder-Kurlanda K., Mayr P., Manshaei K., Thamm M., Vatrapu R., Weller K., Wenz A., Wolf C. (2014). Social Media Monitoring of the Campaigns for the 2013 German Bundestag Elections on Facebook and Twitter. GESIS-Working Papers, 31: 1.

Blumenthal S. (1980). The Permanent Campaign. New York: Simon \& Schuster.

Boccia Artieri G. (2014). Il senso del network. Le scienze sociali computazionali e la sfida dei Big Data. Salute e società, 3, 3: 25. DOI: 10.3280/SES2014-003003.

Boccia Artieri G., ed. (2015). Gli effetti sociali del web. Forme della comunicazione e metodologie della ricerca online. Milano: FrancoAngeli.

Bode L., Hanna A., Yang J., Shah D. V. (2015). Candidate networks, citizen clusters, and political expression: Strategic Hashtag use in the 2010 midterms. The Annals of the American Academy of Political and Social Science, 659, 1: 149. DOI: 10.1177/0002716214563923.

Bond R.M., Fariss C.J., Jones J.J., Kramer A.D., Marlow C., Settle J.E., Fowler J.H. (2012). A 61million-person experiment in social influence and political mobilization. Nature, 489: 295. DOI: 10.1038/nature11421.

Borah P. (2011). Conceptual Issues in Framing Theory: A Systematic Examination of a Decade’s Literature. Journal of Communication, 61, 2: 246. DOI: 10.1111/j.1460-2466.2011.01539.x.

Borah P. (2014). Facebook Use in the 2012 USA Presidential Campaign. In B. Pătruţ, M. Pătruţ, eds., Social Media in Politics: Case Studies on the Political Power of Social Media. New York: Springer.

Borondo J., Morales A. J., Benito R.M., Losada J.C. (2014). Mapping the online communication patterns of political conversations. Physica A: Statistical Mechanics and Its Applications, 414: 403. DOI: 10.1016/j.physa.2014.06.089.

Boyd D., Crawford K. (2012). Critical questions for big data: Provocations for a cultural, technological, and scholarly phenomenon. Information, Communication \& Society, 15, 5: 662. 
Rivista Trimestrale di Scienza dell'Amministrazione - http://www.rtsa.eu - ISSN 0391-190X ISSNe 1972-4942

DOI: 10.1080/1369118X.2012.678878.

Bracciale R., Martella A. (2016). Le «tweeting habit» dei media outlet italiani. Problemi dell'informazione, 3: 505. DOI: 10.1445/84857.

Bracciale R., Martella A. (2017a). Define the populist political communication style: the case of Italian political leaders on Twitter. Information, Communication \& Society, 20, 9: 1310. DOI: 10.1080/1369118X.2017.1328522.

Bracciale R., Martella A. (2017b). Stili di presenza online dei candidati alla Presidenza della Regione Toscana: verso una normalizzazione della sfera pubblica online? In M. Andretta, R. Bracciale, eds.,. Social media campaigning. Le elezioni regionali in \#Toscana2015. Pisa: Pisa University Press.

Broersma M., Graham T. (2012). Social media as beat: Tweets as a news source during the 2010 British and Dutch elections. Journalism Practice, 6, 3: 403. DOI: 10.1080/17512786.2012.663626.

Bruns A. (2016). Tweeting to save the furniture: the 2013 Australian election campaign on Twitter. Media International Australia, 162, 1, 2017: 49. DOI: 10.1177/1329878X16669001.

Bruns A., Burgess J. (2011). \#ausvotes: How Twitter covered the 2010 Australian federal election. Communication, Politics \& Culture, 44, 2: 37.

Bruns A., Burgess J. (2015). Twitter Hashtags from Ad Hoc to Calculated Publics. In Rambukkana N., ed., Hashtag publics: The power and politics of discursive networks. New York: Peter Lang.

Bruns A., Highfield T. (2013). Political networks on Twitter: Tweeting the Queensland state election. Information, Communication \& Society, 16, 5: 667. DOI: 10.1080/1369118X.2013.782328.

Bruns A., Highfield T. (2015). Is Habermas on Twitter? In Bruns A., Enli G., Skogerbø E., Larsson A.O., Christensen Ch., eds., The Routledge Companion to Social Media and Politics. New York: Routledge.

Bruns A., Highfield T. (2016). May the best tweeter win: The Twitter strategies of key campaign accounts in the 2012 US election. In Bieber C., Kamps K., eds., Die US-Präsidentschaftswahl 2012. Wiesbaden: Springer.

Burgess J., Bruns A. (2012). (Not) the Twitter election: The dynamics of the \#ausvotes conversation in relation to the Australian media ecology. Journalism Practice, 6, 3: 384 . DOI: 10.1080/17512786.2012.663610. 
Rivista Trimestrale di Scienza dell'Amministrazione - http://www.rtsa.eu - ISSN 0391-190X ISSNe 1972-4942

Calderón-Monge E. (2017). Twitter to Manage Emotions in Political Marketing. Journal of Promotion Management, 23, 3: 359. DOI: 10.1080/10496491.2017.1294870.

Caplan J. (2013). Social Media and Politics: Twitter Use in the Second Congressional District of Virginia. The Elon Journal of Undergraduate Research in Communications, 4, 1: 5.

Casero-Ripollés A., Sintes-Olivella M., Franch P. (2017). The Populist Political Communication Style in Action: Podemos's Issues and Functions on Twitter During the 2016 Spanish General Election. American Behavioral Scientist. 61, 9: 986. DOI: 10.1177/0002764217707624.

Cepernich C. (2017). Le campagne elettorali al tempo della networked politics. Roma-Bari: Laterza.

Ceron A. (2016). Intra-party politics in 140 characters. Party Politics, 23, 1, 2017: 7. DOI: .1177/1354068816654325.

Ceron A., Curini L., Iacus S.M. (2017). Politics and Big Data: Nowcasting and Forecasting Elections with Social Media. London: Routledge.

Ceron A., d'Adda G. (2015). E-campaigning on Twitter: The effectiveness of distributive promises and negative campaign in the 2013 Italian election. New Media \& Society, 18, 9, 2016: 1935. DOI: $10.1177 / 1461444815571915$.

Chadwick A. (2010). The Political Information Cycle in a Hybrid News System: The British Prime Minister and the "Bullygate” Affair. The International Journal of Press/Politics, 16, 1, 2011: 3. DOI: $10.1177 / 1940161210384730$.

Chadwick A. (2013). The hybrid media system: Politics and power. Oxford, UK: Oxford University Press.

Chadwick A., Dennis J., Smith A.P. (2016). Politics in the Age of Hybrid Media: Power, Systems, and Media Logics. In Bruns A., Enli G., Skogerbø E., Larsson A.O., Christensen Ch., eds., The Routledge Companion to Social Media and Politics. New York: Routledge.

Chadwick A., Howard Ph.N., eds. (2008). Routledge Handbook of Internet Politics. New York: Routledge.

Chi F., Yang N. (2011). Twitter adoption in congress. Review of Network Economics, 10, 1: Article 3. DOI: $10.2202 / 1446-9022.1255$.

Christensen C. (2013). Wave-riding and hashtag-jumping: Twitter, minority "third parties” and the 2012 US elections. Information, Communication \& Society, 16, 5: 646. DOI: 
Rivista Trimestrale di Scienza dell'Amministrazione - http://www.rtsa.eu - ISSN 0391-190X ISSNe 1972-4942

10.1080/1369118X.2013.783609.

Coddington M., Molyneux L., Lawrence R.G. (2014). Fact checking the campaign: How political reporters use Twitter to set the record straight (or not). The International Journal of Press/Politics, 19, 4: 391. DOI: 10.1177/1940161214540942.

Coffey D.J., Kohler M., Granger D.M. (2015). Sparking debate campaigns, social media, and political incivility. In Farrar-Myers V.A., ed., Controlling the message: New media in American political campaigns. New York: New York University Press.

Colleoni E., Rozza A., Arvidsson A. (2014). Echo Chamber or Public Sphere? Predicting Political Orientation and Measuring Political Homophily in Twitter Using Big Data. Journal of Communication, 64, 2: 317.

Conover M.D., Gonçalves B., Flammini A., Menczer F. (2012). Partisan asymmetries in online political activity. EPJ Data Science, 1, 1: 1. DOI: 10.1140/epjds6.

Conover M.D., Ratkiewicz J., Francisco M., Goncalves B., Flammini A., Menczer F. (2011). Political polarization on Twitter. In Nicolov N., Shanahan J.G., Adamic L., Baeza-Yates R., Counts S., eds., Proceedings of the Fifth International AAAI Conference on Weblogs and Social Media. Menlo Park, CA: The AAAI Press.

Conway B.A. Kenski K., Wang D. (2013). Twitter use by presidential primary candidates during the 2012 campaign. American Behavioral Scientist, 57, 11: 1596. DOI: 10.1177/0002764213489014.

Conway B.A., Kenski K., Wang D. (2015). The rise of Twitter in the political campaign: Searching for intermedia agenda-setting effects in the presidential primary. Journal of Computer-Mediated Communication. 20: 363. DOI: 10.1111/jcc4.12124.

Corchia L. (2010). La logica dei processi culturali. Jürgen Habermas tra filosofia e sociologia. Genova: ECIG.

Cornfield M. (2017). Empowering the Party-Crasher: Donald J. Trump, the First 2016 GOP Presidential Debate, and the Twitter Marketplace for Political Campaigns. Journal of Political Marketing, 16, 3-4: 212. DOI: 10.1080/15377857.2017.1345836.

Cornia A. (2014). Restituire l'Imu versata: una proposta shock, ma anche credibile? Analisi dei sondaggi e del dibattito su Twitter. Comunicazione politica, 14, 1: 97. DOI: 10.3270/76590.

D’heer E., Verdegem P. (2014). Conversations about the elections on Twitter: Towards a structural 
Rivista Trimestrale di Scienza dell'Amministrazione - http://www.rtsa.eu - ISSN 0391-190X ISSNe 1972-4942

understanding of Twitter's relation with the political and the media field. European Journal of Communication, 29, 6: 720. DOI: 10.1177/0267323114544866.

Dang-Xuan L., Stieglitz S., Wladarsch J., Neuberger C. (2013). An investigation of influentials and the role of sentiment in political communication on Twitter during election periods. Information, Communication \& Society, 16, 5: 795. DOI: 10.1080/1369118X.2013.783608.

Davenport Th.H. (2015). Big data @l lavoro. Sfatare i miti, scoprire le opportunità. Milano: FrancoAngeli.

Deželan T., Vobič I., Maksuti A. (2014). Twitter Campaigning in the 2011 National Election in Slovenia. Strategy and Application of the Twitter Social Media Outlet in Party Election Campaigns. In Pătruţ B., Pătruţ M., eds., Social Media in Politics: Case Studies on the Political Power of Social Media. New York: Springer.

Di Fatta G., Reade J.J., Jaworska S., Nanda A. (2015). Big Social Data and Political Sentiment: the Tweet Stream during the UK General Election 2015 Campaign. The 8th IEEE International Conference on Social Computing and Networking (SocialCom 2015). Chengdu, China, 19.

Di Fraia G., Missaglia M.C. (2014). The Use of Twitter in 2013 Italian Political Election. In Pătruţ B., Pătruţ M., eds., Social Media in Politics: Case Studies on the Political Power of Social Media. New York: Springer.

Diakopoulos N.A., Shamma D.A. (2010). Characterizing debate performance via aggregated Twitter sentiment. In Mynatt E., Fitzpatrick G., Hudson S., Edwards K., RoddenT., eds., CHI '10: Proceedings of the SIGCHI Conference on Human Factors in Computing Systems. New York, NY: ACM. DOI: 10.1145/1753326.1753504.

DiGrazia J., McKelvey K., Bollen J., Rojas F. (2013). More tweets, more votes: Social media as a quantitative indicator of political behavior. PLoS One, 8, 11: e79449. DOI: 10.1371/journal.pone.0079449.

Dubois E., Gaffney D. (2014). The multiple facets of influence: Identifying political influentials and opinion leaders on Twitter. American Behavioral Scientist, 58, 10: 1260. DOI: 10.1177/0002764214527088.

Dyagilev K., Yom-Tov E. (2013). Linguistic Factors Associated With Propagation of Political Opinions in Twitter. Social Science Computer Review, 32, 2, 2014: 195. DOI: 
Rivista Trimestrale di Scienza dell'Amministrazione - http://www.rtsa.eu - ISSN 0391-190X ISSNe 1972-4942 10.1177/0894439313506850.

Elmer G. (2012). Live research: Twittering an election debate. New Media \& Society, 15, 1, 2013: 18. DOI: $10.1177 / 1461444812457328$.

Engesser S., Ernst N., Esser F., Buchel F. (2016). Populism and Social Media: How Politicians Spread a Fragmented Ideology. Information, Communication \& Society, 20, 8, 2017: 1109. DOI: 10.1080/1369118X.2016.1207697.

Enli G.S. (2017). Twitter as arena for the authentic outsider: Exploring the social media campaigns of Trump and Clinton in the 2016 US presidential election. European Journal of Communication, 32, 1: 50. DOI: $10.1177 / 0267323116682802$

Enli G.S., Naper A. (2016). Social Media Incumbent Advantage: Barack Obama’s and Mitt Romney’s Tweets in the 2012 US Presidential Election Campaign. In Bruns A., Enli G., Skogerbø E., Larsson A.O., Christensen Ch., eds., The Routledge Companion to Social Media and Politics. New York: Routledge.

Enli G.S., Simonsen Ch.-A. (2017). 'Social media logic’ meets professional norms: Twitter hashtags usage by journalists and politicians. Information, Communication \& Society, 21, 8: 1081. DOI: 10.1080/1369118X.2017.1301515.

Enli G.S., Skogerbø E. (2013). Personalized campaigns in party-centered politics: Twitter and Facebook as arenas for political communication. Information, Communication \& Society, 16, 5: 757. DOI: 10.1080/1369118X.2013.782330.

Evans H.K. (2016). Communication with Constituents in 140 Characters: How Members of Congress Used Twitter to Get Out the Vote in 2014. In Davis R., Holtz-Bacha Ch., Just M.R., eds., Twitter and Elections around the World: Campaigning in 140 Characters or less. London: Routledge.

Evans H.K., Clark J.H. (2015). “You Tweet Like a Girl!”. How Female Candidates Campaign on Twitter. American Politics Research, 44, 2, 2016: 326. DOI: 10.1177/1532673X15597747.

Evans H.K., Cordova V., Sipole S. (2014). Twitter style: An analysis of how house candidates used Twitter in their 2012 campaigns. PS: Political Science \& Politics, 47, 2: 454. DOI: 10.1017/S1049096514000389.

Evans H.K., Smith S., Gonzales A., Strouse K. (2017). Mudslinging on Twitter During the 2014 Election. Social Media + Society, First Published May 5: 1. DOI: 10.1177/2056305117704408. 
Faggiano M.P. (2016). L'analisi del contenuto di oggi e di ieri: Testi e contesti on e offline. Milano: FrancoAngeli.

Feller A., Kuhnert M., Sprenger T.O., Welpe I.M. (2011). Divided they tweet: The network structure of political microbloggers and discussion topics. In Nicolov N., Shanahan J.G., Adamic L., BaezaYates R., Counts S., eds., Proceedings of the Fifth International AAAI Conference on Weblogs and Social Media. Menlo Park, CA: The AAAI Press.

Filimonov K., Russmann U., Svensson J. (2016). Picturing the Party: Instagram and Party Campaigning in the 2014 Swedish Elections. Social Media + Society, First Published August 9. DOI: $10.1177 / 2056305116662179$.

Floridia A. (2017). From participation to deliberation. A critical genealogy of deliberative democracy. Colchester, UK: ECPR Press.

Freelon D., Karpf D. (2015). Of big birds and bayonets: Hybrid Twitter interactivity in the 2012 presidential debates. Information, Communication \& Society, 18, 4: 390. DOI: 10.1080/1369118X.2014.952659.

Gaber I. (2016). Twitter. A useful tool for studying elections? Convergence: The International Journal of Research into New Media Technologies, 23, 6: 603. DOI: 10.1177/1354856516646544.

Gainous J., Wagner K.M. (2014). Tweeting to power: The social media revolution in American politics. Oxford, UK: Oxford University Press.

Garrett R.K. (2009). Echo Chambers Online? Politically Motivated Selective Exposure among Internet News Users. Journal of Computer-Mediated Communication, 14, 2: 265. DOI: 10.1111/j.10836101.2009.01440.x.

Gayo-Avello D. (2011). Don’t turn social media into another 'Literary Digest' poll. Communications of the ACM, 54, 10: 121. DOI: 10.1145/2001269.2001297.

Gayo-Avello D. (2013). A meta-analysis of state-of-the-art electoral prediction from Twitter data. Social Science Computer Review, 31, 6: 649. DOI: 10.1177/0894439313493979.

Gibson R.K., McAllister I. (2013). Online Social Ties and Political Engagement. Journal of Information Technology \& Politics, 10, 1: 21. DOI: 10.1080/19331681.2012.712461.

Giglietto F., Rossi L., Bennato D. (2012). The Open Laboratory: Limits and Possibilities of Using Facebook, Twitter, and YouTube as a Research Data Source. Journal of Technology in Human 
Rivista Trimestrale di Scienza dell'Amministrazione - http://www.rtsa.eu - ISSN 0391-190X ISSNe 1972-4942

Services, 30, 3-4: 145.

Gilmore J. (2012). Ditching the pack: Digital media in the 2010 Brazilian congressional campaigns. New Media \& Society, 14, 4: 617. DOI: 10.1080/15228835.2012.743797.

Goodnow T. (2013). Facing Off. A Comparative Analysis of Obama and Romney Facebook Timeline Photographs. American Behavioral Scientist, 57, 11: 1584. DOI: 10.1177/0002764213489013.

Graham T., Jackson D., Broersma M. (2014). New platform, old habits? Candidates' use of Twitter during the 2010 British and Dutch general election campaigns. New Media \& Society, 18, 5, 2016: 765. DOI: $10.1177 / 1461444814546728$.

Groshek J., Al-Rawi A. (2013). Public sentiment and critical framing in social media content during the 2012 U.S. presidential campaign. Social Science Computer Review, 31, 5: 563. DOI: 10.1177/0894439313490401.

Grussel M., Nord L. (2012). Three attitudes to 140 characters: The use and views of Twitter in political party communications in Sweden. Public Communication Review, 2, 2: 48.

Guo L., McCombs M. (2016, eds.). The Power of Information Networks: New Directions for Agenda Setting. New York-London: Routledge.

Guo L., Vargo Ch. (2015). The Power of Message Networks: A Big Data Analysis of the Network Agenda Setting Model and Issue Ownership. Mass Communication and Society, 18, 5: 557. DOI: 10.1080/15205436.2015.1045300.

Habermas J. (1984). The Theory of Communicative Action, Vol. 1. Reason and the Rationalization of Society. Cambridge (UK): Polity Press.

Habermas J. (2006). Political Communication in Media Society: Does Democracy Still Enjoy an Epistemic Dimension? The Impact of Normative Theory on Empirical Research. Collected in Habermas J. (2009). Europe: The Faltering Project. Cambridge (Mass.): MIT Press.

Haleva-Amir S. (2016). Not all about that Facebook: political campaigns and civic engagement in the 2015 elections. Israel Affairs, 22, 3-4: 711. DOI: 10.1080/13537121.2016.1174375.

Haleva-Amir S., Nahon K. (2016). Electoral Politics on Social Media: The Israeli Case. In Bruns A., Enli G., Skogerbø E., Larsson A.O., Christensen Ch., eds., The Routledge Companion to Social Media and Politics. New York: Routledge.

Hanna A., Sayre B., Bode L., Yang J.H., Shah D. (2011). Mapping the political Twitterverse: 
Rivista Trimestrale di Scienza dell'Amministrazione - http://www.rtsa.eu - ISSN 0391-190X ISSNe 1972-4942

Candidates and their followers in the midterms. In Nicolov N., Shanahan J.G., Adamic L., BaezaYates R., Counts S., eds., Proceedings of the Fifth International AAAI Conference on Weblogs and Social Media. Menlo Park, CA: The AAAI Press.

Hanna A., Wells C., Maurer P., Shah D.V., Friedland L., Matthews J. (2013). Partisan alignments and political polarization online: A computational approach to understanding the French and US presidential elections. In I. Weber, A.M. Popescu, M. Pennacchiotti, eds., PLEAD 2013: Proceedings of the Politics, Elections, and Data Workshop. New York, NY: ACM.

Harder R.A., Sevenans J., Van Aelst P. (2017). Intermedia Agenda Setting in the Social Media Age: How Traditional Players Dominate the News Agenda in Election Times. The International Journal of Press/Politics, 22, 3: 275. DOI: 10.1177/1940161217704969.

Hawthorne J., Houston J.B., McKinney M.S. (2013). Live-tweeting a presidential primary debate: Exploring new political conversations. Social Science Computer Review, 31, 5: 552. DOI: 10.1177/0894439313490643.

Hemphill L., Culotta A., Heston M. (2016). \#Polar Scores: Measuring partisanship using social media content. Journal of Information Technology \& Politics, 13, 4: 365. DOI: 10.1080/19331681.2016.1214093.

Hemphill L., Otterbacher J., Shapiro M.A. (2013). What's Congress doing on Twitter? In A. Bruckman, S. Counts, C. Lampe, L. Terveen, eds., CSCW 2013: Proceedings of the 2013 Conference on Computer Supported Cooperative Work Companion. New York: ACM. DOI: 10.1145/2441776.2441876.

Hermans L., Vergeer M. (2012). Personalization in e-campaigning: A cross-national comparison of personalization strategies used on candidate websites of 17 countries in EP elections 2009. New Media \& Society, 15, 1: 2013, 72. DOI: 10.1177/1461444812457333.

Highfield T., Bruns A. (2016). Compulsory Voting, Encouraged Tweeting? Australian Elections and Social Media. In Bruns A., Enli G., Skogerbø E., Larsson A.O., Christensen Ch., eds., The Routledge Companion to Social Media and Politics. New York: Routledge.

Himelboim I., Hansen D., Bowser A. (2013). Playing in the same Twitter network: Political information seeking in the 2010 US gubernatorial elections. Information, Communication \& Society, 16, 9: 1373. DOI: 10.1080/1369118X.2012.706316. 
Himelboim I., McCreery S., Smith M. (2013). Birds of a feather tweet together: Integrating network and content analyses to examine cross-ideology exposure on Twitter. Journal of ComputerMediated Communication, 18, 2: 40. DOI: 10.1111/jcc4.12001.

Himelboim I., Sweetser K.D., Tinkham S.F., Cameron K., Danelo M., West K. (2014). Valence-based homophily on Twitter: Network analysis of emotions and political talk in the 2012 presidential election. New Media \& Society, 18, 7, 2016: 1382. DOI: 10.1177/1461444814555096.

Hoang T.-A., Cohen W.W., Lim E.-P., Pierce D., Redlawsk D.P. (2013). Politics, sharing and emotion in microblogs. In J. Pei, F. Silvestri, J. Tang, eds., ASONAM '13: Proceedings of the 2013 IEEE/ACM International Conference on Advances in Social Networks Analysis and Mining. New York: ACM. DOI: 10.1145/2492517.2492554.

Holtz-Bacha C., Zeh R. (2016). Tweeting to the Press? Political Twitter Activity on Offline Media in the 2013 German Election Campaign. In R. Davis, Ch. Holtz-Bacha, M.R. Just, eds., Twitter and Elections around the World: Campaigning in 140 Characters or less. London: Routledge.

Hong S. (2013). Who benefits from Twitter? Social media and political competition in the U.S. House of Representatives. Government Information Quarterly, 30, 4: 464. DOI: 10.1016/j.giq.2013.05.009.

Hong S., Nadler D. (2011). Does the early bird move the polls? The use of the social media tool “Twitter” by U.S. politicians and its impact on public opinion. In dg.o 2011: Proceedings of the 12th Annual International Conference on Digital Government Research. New York, NY: ACM. DOI: $10.1145 / 2037556.2037583$.

Hong S., Nadler D. (2012). Which candidates do the public discuss online in an election campaign?: The use of social media by 2012 presidential candidates and its impact on candidate salience. Government Information Quarterly, 29, 4: 455. DOI: 10.1016/j.giq.2012.06.004.

Hosch-Dayican B., Amrit C., Aarts K., Dassen A. (2014). How do online citizens persuade fellow voters? Using Twitter during the 2012 Dutch parliamentary election campaign. Social Science Computer Review, 34, 2, 2016: 135. DOI: 10.1177/0894439314558200.

Howison J., Wiggins A., Crowston K. (2011). Validity issues in the use of social network analysis with digital trace data. Journal of the Association for Information Systems, 12, 12: 767.

Hsu C., Park H.W. (2012). Mapping online social networks of Korean politicians. Government 
Rivista Trimestrale di Scienza dell'Amministrazione - http://www.rtsa.eu - ISSN 0391-190X ISSNe 1972-4942

Information Quarterly, 29, 2: 169. DOI: 10.1016/j.giq.2011.09.009.

Huberty M. (2015). Can we vote with our tweet? On the perennial difficulty of election forecasting with social media. International Journal of Forecasting, 31, 3: 992.

Hussain A., Vatrapu R., Hardt D., Ali Jaffari Z., Social Data Analytics Tool: A Demonstrative Case Study of Methodology and Software (2014). In M. Cantijoch, R. Gibson, S. Ward, eds., Analyzing Social Media Data and Web Networks: New Methods for Political Science. Basingstoke: Palgrave Macmillan.

Iannelli L., Giglietto F. (2015). Hybrid spaces of politics: the 2013 general elections in Italy, between talk shows and Twitter. Information, Communication \& Society, 18, 9: 1006. DOI: 10.1080/1369118X.2015.1006658.

Iannelli L., Splendore S. (2017). Participation in the Hybrid Political Newsmaking and Its Consequences on journalism epistemology. Comunicazioni sociali, 3: 436.

İkiz O.O., Sobaci M.Z. Yavuz N., Karkin N. (2014). Political use of Twitter: The case of metropolitan mayor candidates in 2014 local elections in Turkey. In E. Estevez, M. Janssen, L. Soares Barbosa, eds., ICEGOV '14: Proceedings of the 8th International Conference on Theory and Practice of Electronic Governance. New York, NY: ACM. DOI: 10.1145/2691195.2691219.

Jackson N.A., Lilleker D.G. (2009). MPs and E-representation: Me, MySpace and I. British Politics, 4, 2: 236. DOI: 10.1057/bp.2009.2.

Jackson N.A., Lilleker D.G. (2011). Microblogging, constituency service and impression management: UK MPs and the use of Twitter. Journal of Legislative Studies, 17, 1: 86. DOI: 10.1080/13572334.2011.545181.

Jaidka K., Ahmed S. (2015). The 2014 Indian general election on Twitter: An analysis of changing political traditions. In A. Chib, M. Kam, J. Burrell, eds., ICTD '15: Proceedings of the Seventh International Conference on Information and Communication Technologies and Development (Number 43). New York: ACM. DOI: 10.1145/2737856.2737889.

Jennings F.J., Coker C.R., McKinney M.S., Warner B.R. (2017). Tweeting Presidential Primary Debates: Debate Processing Through Motivated Twitter Instruction. American Behavioral Scientist, 61, 4: 455. DOI: 10.1177/0002764217704867.

Jensen J.L., Ørmen J., Lomborg S. (2016). The Use of Twitter in the Danish EP Elections 2014. In 
Bruns A., Enli G., Skogerbø E., Larsson A.O., Christensen Ch., eds., The Routledge Companion to Social Media and Politics. New York: Routledge.

Jensen M.J. (2016). Social Media and Political Campaigning: Changing Terms of Engagement?. The International Journal of Press/Politics, 22, 1: 23. DOI: 10.1177/1940161216673196.

Jungherr A. (2013). Tweets and votes, a special relationship: The 2009 federal election in Germany. In

I. Weber, A.M. Popescu, M. Pennacchiotti, eds., PLEAD 2013: Proceedings of the Politics, Elections and Data Workshop. New York: ACM. DOI: 10.1145/2508436.2508437.

Jungherr A. (2014). The logic of political coverage on Twitter: Temporal dynamics and content. Journal of Communication, 64, 2: 239. DOI: 10.1111/jcom.12087.

Jungherr A. (2015). Analyzing political communication with digital trace data: The role of Twitter messages in social science research. Heidelberg: Springer.

Jungherr A. (2016a). Twitter use in election campaigns: A systematic literature review. Journal of Information Technology \& Politics, 13, 1: 72. DOI: 10.1080/19331681.2015.1132401.

Jungherr A. (2016b). Four functions of digital tools in election campaigns: The German case. The International Journal of Press/Politics, 21, 3: 358. DOI: $10.1177 / 1940161216642597$.

Jungherr A., Schoen H., Jürgens P. (2016). The mediation of politics through Twitter: An analysis of messages posted during the campaign for the German federal election 2013. Journal of ComputerMediated Communication, 21, 1: 50. DOI: 10.1111/jcc4.12143.

Jungherr A., Schoen H., Posegga O., Jürgens P. (2017). Digital Trace Data in the Study of Public Opinion. An Indicator of Attention toward Politics Rather Than Political Support. Social Science Computer Review, 35, 3: 336. DOI: 10.1177/0894439316631043.

Jürgens P., Jungherr A. (2015). The use of Twitter during the 2009 German national election. German Politics, 24, 4: 469. DOI: 10.1080/09644008.2015.1116522.

Jürgens P., Jungherr A., Schoen H. (2011). Small worlds with a difference: New gatekeepers and the filtering of political information on Twitter. In D. De Roure, S. Poole, eds., WebSci '11 Proceedings of the 3rd international web science conference. New York: ACM. DOI: $10.1145 / 2527031.2527034$.

Just M.R., Crigler A.N., Owen R.A. (2016). Candidate Use of Twitter and the Intersection of Gender, Party, and Position in the Race: A Comparison of Competitive Male/Female Senate Races in 2012 
Rivista Trimestrale di Scienza dell'Amministrazione - http://www.rtsa.eu - ISSN 0391-190X ISSNe 1972-4942

and 2014. In R. Davis, Ch. Holtz-Bacha, M.R. Just, eds., Twitter and Elections around the World: Campaigning in 140 Characters or less. London: Routledge.

Kalsnes B. (2016). The Social Media Paradox Explained: Comparing Political Parties’ Facebook Strategy Versus Practice. Social Media + Society, First Published May 17: 1. DOI: 10.1177/2056305116644616.

Kalsnes B., Krumsvik A. H., Storsul T. (2014). Social media as a political backchannel. Aslib Journal of Information Management, 66, 3: 313. DOI: 10.1108/AJIM-09-2013-0093.

Kanungo N.T. (2015). India’s Digital Poll Battle: Political Parties and Social Media in the 16th Lok Sabha Elections. Studies in Indian Politics, 3, 2: 212. DOI: 10.1177/2321023015601743.

Karlsen R., Enjolras B. (2016). Styles of Social Media Campaigning and Influence in a Hybrid Political Communication System: Linking Candidate Survey Data with Twitter Data. The International Journal of Press/Politics, 21, 3: 338. DOI: 10.1177/1940161216645335.

Karpf D. (2012). Social Science Research Methods in Internet Time. Information, Communication \& Society, 15, 5: 639. DOI: 10.1080/1369118X.2012.665468.

Kercher J., Bachl M. (2016). Campaigning on YouTube Output und Outcome im YouTubeWahlkampf zur US-Präsidentschaftswahl 2012. In Ch. Bieber, K. Kamps, eds., Die USPräsidentschaftswahl 2012. Analysen der Politik- und Kommunikationswissenschaft. Wiesbaden: Springer.

Kim J., Yoo J. (2012). Role of Sentiment in Message Propagation: Reply vs. Retweet Behavor in Political Communication, 2012 International Conference on Social Informatics, Lausanne, CH: IEEE. DOI: 10.1109/SocialInformatics.2012.33.

King A.S., Orlando F.J., Sparks D.B (2015). Ideological Extremity and Success in Primary Elections. Drawing Inferences from the Twitter Network. Social Science Computer Review, 34, 4, 2016: 395. DOI: $10.1177 / 0894439315595483$.

Klašnja M., Barberá P., Beauchamp N., Nagler J., Tucker J. (2017). Measuring Public Opinion with Social Media Data. In R.M. Alvarez, L. Atkeson, eds., The Oxford Handbook of Polling and Survey Methods. Oxford: Oxford University Press.

Klinger U. (2013). Mastering the art of social media: Swiss parties, the 2011 national election and digital challenges. Information, Communication \& Society, 16, 5: 717. DOI: 
Rivista Trimestrale di Scienza dell'Amministrazione - http://www.rtsa.eu - ISSN 0391-190X ISSNe 1972-4942

10.1080/1369118X.2013.782329.

Klinger U., Svensson J. (2016). Network Media Logic. Some Conceptual Considerations. In Bruns A., Enli G., Skogerbø E., Larsson A.O., Christensen Ch., eds., The Routledge Companion to Social Media and Politics. New York: Routledge.

Kreiss D. (2016). Seizing the moment: The presidential campaigns' use of Twitter during the 2012 electoral cycle. New Media \& Society, 18, 8: 1473. DOI: 10.1177/1461444814562445.

Kruikemeier S. (2014). How political candidates use Twitter and the impact on votes. Computers in Human Behavior, 34: 131. DOI: 10.1016/j.chb.2014.01.025.

LaMarre H.L., Suzuki-Lambrecht Y. (2013). Tweeting democracy? Examining Twitter as an online public relations strategy for congressional campaigns. Public Relations Review, 39, 4: 360. DOI: 10.1016/j.pubrev.2013.07.009.

Larsson A.O. (2015). Going viral? Comparing parties on social media during the 2014 Swedish election. Convergence: The International Journal of Research into New Media Technologies, 23, 2, 2017: 117. DOI: $10.1177 / 1354856515577891$.

Larsson A.O. (2017). Top Users and Long Tails: Twitter and Instagram Use during the 2015 Norwegian Elections. Social Media + Society, First Published June 15. DOI: 10.1177/2056305117713776.

Larsson A.O., Hallvard M. (2011). Studying political microblogging: Twitter users in the 2010 Swedish election campaign. New Media \& Society, 14, 5, 2012: 729. DOI: 10.1177/1461444811422894.

Larsson A.O., Moe H. (2013). Representation or participation? Twitter use during the 2011 Danish election campaign. Javnost-The Public, 20, 1: 71. DOI: 10.1080/13183222.2013.11009109.

Larsson A.O., Moe H. (2016). From Emerging to Established? A Comparison of Twitter Use during Swedish Election Campaigns in 2010 and 2014. In Bruns A., Enli G., Skogerbø E., Larsson A.O., Christensen Ch., eds., The Routledge Companion to Social Media and Politics. New York: Routledge.

Lassen D.S., Brown A.R. (2010). Twitter: The electoral connection? Social Science Computer Review, 29, 4, 2011: 419. DOI: 10.1177/0894439310382749.

Lawrence R.G., Molyneux L., Coddington M., Holton A. (2014). Tweeting conventions: Political 
Rivista Trimestrale di Scienza dell'Amministrazione - http://www.rtsa.eu - ISSN 0391-190X ISSNe 1972-4942 journalists' use of Twitter to cover the 2012 presidential campaign. Journalism Studies, 15, 6: 789. DOI: 10.1080/1461670X.2013.836378.

Lazer D., Pentland A., Adamic L., Aral S., Barabasi A.L., Brewer D., Christakis N., Contractor N., Fowler J., Gutmann M., Jebara T., King G., Macy M., Roy D., Van Alstyne M., (2009). Computational Social Science. Science, 323, 5915: 721. DOI: 10.1126/science.1167742.

Lietz H., Wagner C., Bleier A., Strohmaier M. (2014). When politicians talk: Assessing online conversational practices of political parties on Twitter. In E. Adar, P. Resnick, M. De Choudhury, B. Hogan, eds., ICWSM 2014: Proceedings of the 8th International AAAI Conference on Weblogs and Social Media. Menlo Park: Association for the Advancement of Artificial Intelligence (AAAI).

Lilleker D.G., Jackson N., Koc-Michalska K. (2016). Social Media in the UK Election Campaigns 2008-2014: Experimentation, Innovation and Convergence. In Bruns A., Enli G., Skogerbø E., Larsson A.O., Christensen Ch., eds., The Routledge Companion to Social Media and Politics. New York: Routledge.

Lin H.C. (2017). How Political Candidates' Use of Facebook Relates to the Election Outcomes. International Journal of Market Research, 59, 1: 77. DOI: 10.2501/IJMR-2017-004.

Lin Y.R., Keegan B., Margolin D., Lazer D. (2014). Rising tides or rising stars?: Dynamics of shared attention on Twitter during media events. PLoS ONE, 9, 5: e94093. DOI: 10.1371/journal.pone.0094093.

Livne A., Simmons M.P., Adar E., Adamic L.A. (2011). The party is over here: Structure and content in the 2010 election. IIn Nicolov N., Shanahan J.G., Adamic L., Baeza-Yates R., Counts S., eds., Proceedings of the Fifth International AAAI Conference on Weblogs and Social Media. Menlo Park, CA: The AAAI Press.

Lombi L., Marzulli M., eds. (2017). Theorising Sociology in the Digital Society. Milano: FrancoAngeli.

López García G. (2015). El debate sobre Europa en Twitter. Discursos y estrategias de los candidatos de las elecciones al Parlamento Europeo de 2014 en España. Revista de Estudios políticos, 170: 213. DOI: $10.18042 /$ cepc/rep.170.07.

Lukamto W., Carson A. (2016). POLITWEETS: social media as a platform for political engagement between Victorian politicians and citizens, Communication Research and Practice, 2, 2: 191. DOI: 
Rivista Trimestrale di Scienza dell'Amministrazione - http://www.rtsa.eu - ISSN 0391-190X ISSNe 1972-4942

10.1080/22041451.2016.1186485.

Lyons B.A., Veenstra A.S. (2016). How (not) to talk on Twitter: Effects of politicians’ Tweets on perceptions of the Twitter environment. Cyberpsychology, Behavior, and Social Networking, 19, 1: 8. DOI: 10.1089/cyber.2015.0319.

Macnamara J. (2011). Pre and post-election 2010 online: What happened to the conversation? Communication, Politics \& Culture, 44, 2: 18.

Macnamara J., Kenning G. (2011). E-Electioneering 2010: Trends in Social Media Use in Australian Political Communication. Media International Australia, 139, 1: $7 . \quad$ DOI: 10.1177/1329878X1113900104.

MacWilliams M.C. (2015). Forecasting congressional elections using Facebook data. PS: Political Science \& Politics, 48, 4: 579. DOI: 10.1017/S1049096515000797.

Manovich I. (2012). Trending: The promises and the challenges of big social data. In M.K. Gold, ed., Debates in the digital humanities. Minneapolis: University of Minnesota Press.

Marchetti R., Ceccobelli D. (2015). Twitter and Television in a Hybrid Media System: The 2013 Italian election campaign. Journalism Practice, 10, 5, 2016: 626. DOI: 10.1080/17512786.2015.1040051.

Margaretten M., Gaber I. (2014). The crisis in public communication and the pursuit of authenticity: An analysis of the Twitter feeds of Scottish MPs 2008-2010. Parliamentary Affairs, 67, 2: 328. DOI: $10.1093 / \mathrm{pa} / \mathrm{gss} 043$.

Marquis L. (2016). Priming. In G. Mazzoleni, K.G. Barnhurst, K. Ikeda, R.C.M. Maia, H. Wessler, eds., The International Encyclopedia of Political Communication. Vol. I. Malden, MA, Oxford, Wiley Blackwell.

Mascaro C. M., Black A., Goggins S. (2012). Tweet recall: Examining real-time civic discourse on Twitter. In T.A. Finholt, H. Tellioğlu, K. Inkpen, T. Gross, eds., GROUP 2012: Proceedings of the 17th ACM International Conference on Supporting Group Work. New York, NY: ACM. DOI: 10.1145/2389176.2389233.

Mazzoleni G., Sfardini A. (2009). Politica pop. Da «Porta a porta» a «L’isola dei famosi». Bologna: il Mulino.

McGregor S.C. (2017). Personalization, social media, and voting: Effects of candidate self- 
Rivista Trimestrale di Scienza dell'Amministrazione - http://www.rtsa.eu - ISSN 0391-190X ISSNe 1972-4942

personalization on vote intention. New Media \& Society, 20, 3, 2018: 1139. DOI: $10.1177 / 1461444816686103$.

McGregor S.C., Mourão R.R. (2016). Talking Politics on Twitter: Gender, Elections, and Social Networks. Social Media + Society, First Published August 17, 1.

McGregor S.C., Mourão R.R., Molyneux L. (2017). Twitter as a tool for and object of political and electoral activity: Considering electoral context and variance among actors, Journal of Information Technology \& Politics, 14, 2: 154. DOI: 10.1080/19331681.2017.1308289.

McKelvey K., DiGrazia J., Rojas F. (2014). Twitter publics: How online political communities signaled electoral outcomes in the 2010 US House election. Information, Communication \& Society, 17, 4: 436. DOI: 10.1080/1369118X.2014.892149.

McKinney M.S., Houston J.B., Hawthorne J. (2013). Social Watching a 2012 Republican Presidential Primary Debate. American Behavioral Scientist, 58, 4, 2014: 556. DOI: 10.1177/0002764213506211.

Meeksm L. (2015). Aligning and Trespassing. Candidates' Party-Based Issue and Trait Ownership on Twitter. Journalism \& Mass Communication Quarterly, 93, 4, 2016: 1050. DOI: 10.1177/1077699015609284.

Mejova Y., Srinivasan P., Boynton B. (2013). GOP primary season on Twitter: "Popular" political sentiment in social media. In P. Ferragina, A. Gionis, eds., WSDM '13: Proceedings of the Sixth ACM International Conference on Web Search and Data Mining. New York: ACM. DOI: 10.1145/2433396.2433463.

Metaxas P.T., Mustafaraj E., Gayo-Avello D. (2011). How (Not) to Predict Elections. In Proceedings of PASSAT/SocialCom 2011, 2011 IEEE Third International Conference on Privacy, Security, Risk and Trust (PASSAT) and 2011 IEEE Third International Conference on Social Computing (SocialCom), IEEE Computer Society. Los Alamitos, CA: IEEE. DOI: 10.1109/PASSAT/SocialCom.2011.98.

Miller Noah W., Ko Rosa S. (2015), Studying Political Microblogging: Parliamentary Candidates on Twitter During the February 2012 Election in Kuwait. International Journal of Communication, 9: 2933.

Mirer M. L., Bode L. (2013). Tweeting in defeat: How candidates concede and claim victory in 140 
Rivista Trimestrale di Scienza dell'Amministrazione - http://www.rtsa.eu - ISSN 0391-190X ISSNe 1972-4942

characters. New Media \& Society, 17, 3, 2015: 453. DOI: 10.1177/1461444813505364.

Moe H., Larsson A.O. (2013). Untangling a complex media system: A comparative study of Twitterlinking practices during three Scandinavian election campaigns. Information, Communication \& Society, 16, 5: 775. DOI: 10.1080/1369118X.2013.78360.

Murchison A. (2015). Changing Communications? Political Parties and Web 2.0 in the 2011 New Zealand General Election. In G. Lachapelle, Ph. Maarek, eds., Political Parties in the Digital Age: The Impact of New Technologies in Politics. Oldenburg: De Gruyter.Chr

Murthy D. (2015). Twitter and elections: are tweets, predictive, reactive, or a form of buzz?. Information, Communication \& Society, 18, 7: 816. DOI: 10.1080/1369118X.2015.1006659.

Murthy D., Petto L.R. (2014). Comparing print coverage and tweets in elections: A case study of the 2011-2012 U.S. Republican primaries. Social Science Computer Review, 33, 3, 2015: 298. DOI: 10.1177/0894439314541925.

Mustafaraj E., Finn Y., Whitlock C., Metaxas P.T. (2011). Vocal minority versus silent majority: Discovering the opinions of the long tail. In SocialCom 2011: The 3rd IEEE International Conference on Social Computing. Washington, DC: IEEE.

Neuman W.R., Guggenheim L., Mo Jang S., Bae S.Y. (2014). The dynamics of public attention: Agenda-setting theory meets big data. Journal of Communication, 64, 2: 193. DOI: 10.1111/jcom.12088.

Ngomba T. (2016). Social Media and Election Campaigns in Sub-Saharan Africa: Insights from Cameroon. In Bruns A., Enli G., Skogerbø E., Larsson A.O., Christensen Ch., eds., The Routledge Companion to Social Media and Politics. New York: Routledge.

Nooralahzadeh F., Arunachalam V., Chiru C.G. (2013). 2012 Presidential elections on Twitter: An analysis of how the US and French election were reflected in tweets. In I. Dumitrache, A.M. Florea, F. Pop, eds., CSCS '13: Proceedings of the 2013 19th International Conference on Control Systems and Computer Science. Washington: IEEE Computer Society. DOI: 10.1109/CSCS.2013.72.

Nuernbergk Ch., Conrad J. (2016). Conversations and Campaign Dynamics in a Hybrid Media Environment: Use of Twitter by Members of the German Bundestag. Social Media + Society, 2, 1, First Published February 16: 1. DOI: 10.1177/2056305116628888. 
Nuernbergk Ch., Wladarsch J., Neubarth J., Neuberger Ch. (2016). Social Media Use in the German Election Campaign 2013. In Bruns A., Enli G., Skogerbø E., Larsson A.O., Christensen Ch., eds., The Routledge Companion to Social Media and Politics. New York: Routledge.

Oelsner K., Heimrich L. (2015). Social media use of German politicians: towards dialogic voter relations? German Politics, 24, 4: 451. DOI: 10.1080/09644008.2015.1021790.

Pablo Z.C., Oco N., Roldan M.D.G., Cheng C., Roxas R.E. (2014). Toward an enriched understanding of factors influencing Filipino behavior during elections through the analysis of Twitter data. Philippine Political Science Journal, 35, 2: 203. DOI: 10.1080/01154451.2014.964794.

Papa F., Francony J.-M. (2016). The 2012 French Presidential Campaign: First Steps into the Political Twittersphere. In Bruns A., Enli G., Skogerbø E., Larsson A.O., Christensen Ch., eds., The Routledge Companion to Social Media and Politics. New York: Routledge.

Papacharissi Z.A. (2014). Affective publics: Sentiment, technology, and politics. Oxford, UK: Oxford University Press.

Pariser E. (2011). The filter bubble: What the Internet is hiding from you. New York, NY: Penguin.

Park H.W. (2014). Mapping election campaigns through negative entropy: Triple and quadruple helix approach to South Korea's 2012 presidential election. Scientometrics, 99, 1: 187. DOI: 10.1007/s11192-013-1122-5.

Parmelee J.H., Bichard S.L. (2012). Politics and the Twitter revolution: How tweets influence the relationship between political leaders and the public. Plymouth, UK: Lexington Books.

Paternostro G. (2015). Un tweet ci seppellirà? Il nuovo ordine del discorso politico nell’Italia postberlusconiana. Rivista Trimestrale di Scienza dell'Amministrazione, 3: 103. DOI: 10.3280/SA2015003008.

Pătruţ M. (2017). The 2014 presidential elections campaign in Romania. Connecting with civicness on Facebook. In P. Surowiece V. Štětka, eds., Social Media and Politics in Central and Eastern Europe. Routledge: London.

Pavan E., Caiani M. (2017). «Solidarietà sconvenienti». Reti online di estrema destra contro e per la riforma dell’Europa. Comunicazione Politica, 17, 3: 359. DOI: 10.3270/87969.

Perloff R. M. (2013). The Dynamics of Political Communication. Media and Politics in a Digital Age. New York: Routledge. 
Peterson R.D. (2012). To tweet or not to tweet: Exploring the determinants of early adoption of Twitter by House members in the 111th Congress. The Social Science Journal, 49, 4: 430. DOI: 10.1016/j.soscij.2012.07.002.

Plotkowiak T., Stanoevska-Slabeva K. (2013). German politicians and their Twitter networks in the Bundestag election 2009. First Monday, 18, 5. DOI: 10.5210/fm.v18i5.3816.

Polat F., Özdeşim S.Ö. (2016). The Use of Twitter by Politicians during June 2015 and November 2015 General Elections the Case of PDP. European Journal of Multidisciplinary Studies, 1, 2: 362. DOI: 10.26417/ejms.v1i2.p361-368.

Prémont K., Millette Ch.-A. (2015). Social Media and American Presidential Campaigns: The Dark Side of the Electoral Process. In G. Lachapelle, Maarek Ph., eds., Political Parties in the Digital Age: The Impact of New Technologies in Politics. Oldenburg: De Gruyter.

Quinlan S., Gummer T., Roßmann J., Wolf Ch. (2017). 'Show me the money and the party!' Variation in Facebook and Twitter adoption by politicians. Information, Communication \& Society, 21, 8, 2018: 1031. DOI: 10.1080/1369118X.2017.1301521.

Ramos-Serrano M., Fernández Gómez G.D., Pineda A. (2016). 'Follow the closing of the campaign on streaming': The use of Twitter by Spanish political parties during the 2014 European elections. New Media \& Society, 20, 1, 2018: 122. DOI: 10.1177/1461444816660730.

Rathnayake C., Buente W (2017). Incidental Effects of Automated Retweeting: An Exploratory Network Perspective on Bot Activity during Sri Lanka's Presidential Election in 2015. Bulletin of Science, Technology \& Society, 37, 1: 57. DOI: 10.1177/0270467617736219.

Raynauld V., Greenberg J. (2014). Tweet, click, vote: Twitter and the 2010 Ottawa municipal election. Journal of Information Technology \& Politics, 11, 4: 412. DOI: 10.1080/19331681.2014.935840.

Recuero R., Zago G., Bastos M.T. (2016). Twitter in Political Campaigns: The Brazilian 2014 Presidential Election. In Bruns A., Enli G., Skogerbø E., Larsson A.O., Christensen Ch., eds., The Routledge Companion to Social Media and Politics. New York: Routledge.

Reimar Z. (2016). From a Tweet to a Seat: Twitter, Media Visibility, and Electoral Support. In R. Davis, Ch. Holtz-Bacha, M.R. Just, eds., Twitter and Elections around the World: Campaigning in 140 Characters or less. London: Routledge.

Romero R.C. (2015). Politics 2.0 ICTs in Costa Rica’s 2014 Presidential Campaign. International 
Rivista Trimestrale di Scienza dell'Amministrazione - http://www.rtsa.eu - ISSN 0391-190X ISSNe 1972-4942

Conference on Information Society (i-Society): 115. DOI: 10.1109/i-Society.2015.7366870.

Rossi L., Orefice M. (2016). Comparing Facebook and Twitter during the 2013 General Election in Italy. In Bruns A., Enli G., Skogerbø E., Larsson A.O., Christensen Ch., eds., The Routledge Companion to Social Media and Politics. New York: Routledge.

Rowe I. (2015). Civility 2.0: A comparative analysis of incivility in online political discussion. Information, Communication \& Society, 18: 121. DOI: 10.1080/1369118X.2014.940365.

Ryoo J., Bendle N. (2017). Understanding the Social Media Strategies of U.S. Primary Candidates. Journal of Political Marketing, 16, 3-4: 244. DOI: 10.1080/15377857.2017.1338207.

Sanjari A., Khazraee E. (2014), Information diffusion using Twitter: A case study of Twitter for Iranian presidential election, 2013. In M. Strohmaier, C. Cattuto, E. Meyer, eds., WebSci '14: Proceedings of the 2014 ACM Conference on Web Science. New York: ACM.

Santaniello M., Palladino N., Vitale P. (2017). Populisti vs. Cosmopoliti. Le trasformazioni del linguaggio politico tra le campagne presidenziali USA del 2012 e 2016. Comunicazione Politica, 17, 3: 407. DOI: 10.3270/87971.

Schacter D.L. (1992). Priming and multiple memory systems: Perceptual mechanisms of implicit memory. Journal of Cognitive Neuroscience, 4, 3: 244. DOI: 10.1162/jocn.1992.4.3.244

Seizov O. (2015). Communicative and Persuasive Strategies in the Bulgarian Parliamentary Elections 2014. International Journal of E-Politics, 6, 2: 43. DOI: 10.4018/IJEP.2015040104.

Settle J.E., Fariss Ch.J., Bond R.M., Jones J.J., Fowler J.H., Coviello L., Kramer A.D.I., Marlow C. (2015). From Posting to Voting: The Effects of Political Competition on Online Political Engagement. Political Science Research and Methods, 4, 2, 2016: 361. DOI: 10.1017/psrm.2015.1.

Shah C., Yazdani Nia T. (2011). Politics 2.0 with Facebook - Collecting and Analyzing Public Comments on Facebook for Studying Political Discourses. The Journal of Information Technology and Politics. Annual Conference 2011: The Future of Computational Social Science, 3.

Shah D.V., Hanna A., Bucy E.P., Wells C., Quevedo V. (2015). The power of television images in a social media age: Linking biobehavioral and computational approaches via the second screen. The Annals of the American Academy of Political and Social Science, 659, 1: 225. DOI: 10.1177/0002716215569220.

Shamma, D.A., Kennedy, L., Churchill, E.F. (2009). Tweet the debates: Understanding community 
Rivista Trimestrale di Scienza dell'Amministrazione - http://www.rtsa.eu - ISSN 0391-190X ISSNe 1972-4942

annotation of uncollected sources. In Boll S., Hoi S.C.H., Luo J., Jin R., King I., Xu D., eds., WSM '09: Proceedings of the first ACM SIGMM International Workshop on Social Media. New York: ACM. DOI: 10.1145/1631144.1631148.

Shaw D., Weaver D. (2014). Media agenda-setting and audience agenda-melding. In McCombs M.E., ed., Setting the agenda: The mass media and public opinion. Cambridge: Polity Press.

Shephard M., Quinlan S. (2016). Social Media and the Scottish Independence Referendum 2014: Events and the Generation of Enthusiasm for Yes. In Bruns A., Enli G., Skogerbø E., Larsson A.O., Christensen Ch., eds., The Routledge Companion to Social Media and Politics. New York: Routledge.

Shin J., Jian L., Driscoll K., Bar F. (2016). Political rumoring on Twitter during the 2012 US presidential election: Rumor diffusion and correction. New Media \& Society, 19, 8, 2017: 1214. DOI: $10.1177 / 1461444816634054$.

Shogan C.J. (2010). Blackberries, tweets, and YouTube: Technology and the future of communicating with Congress. PS: Political Science \& Politics, 43, 2: 231. DOI: 10.1017/S1049096510000041.

Skoric M., Poor N., Achananuparp Pl, Lim E.P., Jiang J. (2012). Tweets and Votes: A Study of the 2011 Singapore General Election. In Proceedings of 45th Hawaii International International Conference on Systems Science (HICSS45 2012), IEEE Computer Society. Los Alamitos, CA: IEEE. DOI: 10.1145/2508436.2508437.

Skovsgaard M., Van Dalen A. (2016). Not Just a Face(book) in the Crowd: Candidates' Use of Facebook during the Danish 2011 Parliamentary Election Campaign. In Bruns A., Enli G., Skogerbø E., Larsson A.O., Christensen Ch., eds., The Routledge Companion to Social Media and Politics. New York: Routledge.

Small T.A. (2010). Canadian politics in 140 characters: Party politics in the Twitterverse. Canadian Parliamentary Review, 33, 3: 39.

Small T.A. (2011). What the hashtag? A content analysis of Canadian politics on Twitter. Information, Communication \& Society, 14, 6: 872. DOI: 10.1080/1369118X.2011.554572.

Small T.A. (2016). Parties, Leaders, and Online Personalization: Twitter in Canadian Electoral Politics. In R. Davis, Ch. Holtz-Bacha, M.R. Just, eds., Twitter and Elections around the World: Campaigning in 140 Characters or less. London: Routledge. 
Song M., Kim M.C., Jeong Y.K. (2014). Analyzing the political landscape of 2012 Korean presidential election in Twitter. IEEE Intelligent Systems, 29, 2: 18. DOI: 10.1109/MIS.2014.20.

Spaiser V., Chadefaux Th., Donnay K., Russmann F., Helbing D. (2017). Communication power struggles on social media: A case study of the 2011-12 Russian protests, Journal of Information Technology \& Politics, 14, 2: 132. DOI: 10.1080/19331681.2017.1308288.

Splendore S., Rega R. (2017). The mediatization of politics in the hybrid media system: The case of Italian political journalism. Northern Lights, 15, 1: 111. DOI: 10.1386/nl.15.111-1.

Sreekumar, T.T., Vadrevu, S. (2013). Subpolitics and democracy: The role of new media in the 2011 general elections in Singapore. Science Technology \& Society, 18, 2: 231. DOI: 10.1177/0971721813489458.

Štětka V., Macková A., Fialová M. (2014). A Winding Road from “Likes” to Votes. The Role of Social Media in the 2013 Czech Presidential Elections. In Pătruţ B., Pătruţ M. (eds). Social Media in Politics: Case Studies on the Political Power of Social Media. New York: Springer.

Stieglitz S., Brockmann T., Xuan L.D. (2012). Usage of Social Media for Political Communication. PACIS 2012 Proceedings. Paper 22.

Stieglitz S., Dang-Xuan L. (2012). Political communication and influence through microblogging: An empirical analysis of sentiment in Twitter messages and retweet behavior. In Sprague R.H. Jr., ed., HICSS 2012: Proceedings of the 45th Hawaii International Conference on System Science. Washington, DC: IEEE Computer Society. DOI: 10.1109/HICSS.2012.476.

Strandberg K. (2013). A social media revolution or just a case of history repeating itself? The use of social media in the 2011 Finnish parliamentary elections. New Media \& Society, 15, 8: 1329. DOI: $10.1177 / 1461444812470612$.

Straus J.R., Glassman M.E., Shogan C.J., Navarro Smelcer S. (2013). Communicating in 140 characters or less: Congressional adoption of Twitter in the 111th Congress. PS: Political Science \& Politics, 46, 1: 60. DOI: 10.1017/S1049096512001242.

Stromer-Galley J. (2014). Presidential Campaigning in the Internet Age. Oxford: Oxford University Press.

Sudhahar S., Veltri G.A., Cristianini N. (2015). Automated analysis of the US presidential elections using Big Data and network analysis. Big Data \& Society, 2, 1. DOI: 10.1177/2053951715572916. 
Suiter J. (2015). Political campaigns and social media: A study of \#mhe13 in Ireland. Irish Political Studies, 30, 2: 299. DOI: 10.1080/07907184.2015.1018899.

Sunstein C.R. (2007). Republic.com 2.0. Revenge of the Blogs. Princeton, NJ: Princeton University Press.

Tjong Kim Sang, E., Bos, J. (2012). Predicting the 2011 Dutch Senate Election Results with Twitter, 13th Conference of the European Chapter of the Association for Computational Linguistics, Avignon, FR, 23-27.4.2012.

Trilling D. (2014). Two different debates? Investigating the relationship between a political debate on TV and simultaneous comments on Twitter. Social Science Computer Review, 33, 3, 2015: 259. DOI: $10.1177 / 0894439314537886$.

Tsakalidis A., Papadopoulos S., Cristea A. I., Kompatsiaris Y. (2015). Predicting elections for multiple countries using Twitter and polls. IEEE Intelligent Systems, 30: 10. DOI: 10.1109/MIS.2015.17.

Tumasjan A., Sprenger T.O. Sandner Ph.G., Welpe I.M. (2010). Election Forecasts With Twitter: How 140 Characters Reflect the Political Landscape. Social Science Computer Review, 29, 4, 2011: 402. DOI: $10.1177 / 0894439310386557$.

Uenohara H. (2014). Internet Campaign in the 2013 House of Councillors Election : the Analysis of Candidates' Use of Twitter. Japanese Journal of Election Studies, 30, 2: 116. DOI: 10.14854/jaes.30.2_116.

Vaccari C., Valeriani A. (2013). Follow the leader! Direct and indirect flows of political communication during the 2013 general election campaign. New Media \& Society, 17, 7, 2015: 1025. DOI: $10.1177 / 1461444813511038$.

van Dijck J., Poell T. (2013). Understanding social media logic. Media and Communication, 1, 1: 2. DOI: $10.17645 /$ mac.v1i1.70.

Van Kessel S., Castelein R. (2016). Shifting the blame. Populist politicians' use of Twitter as a tool of opposition'. Journal of Contemporary European Research, 12, 2: 594.

Vargo C.J., Guo L., McCombs M., Shaw D.L. (2014). Network issue agendas on Twitter during the 2012 U.S. presidential election. Journal of Communication, 64, 2: 296. DOI: 10.1111/jcom.12089. Vargo C.J., Hopp T. (2017). Socioeconomic Status, Social Capital, and Partisan Polarity as Predictors 
Rivista Trimestrale di Scienza dell'Amministrazione - http://www.rtsa.eu - ISSN 0391-190X ISSNe 1972-4942

of Political Incivility on Twitter. Social Science Computer Review archive, 35, 1: 10. DOI: 10.1177/0894439315602858.

Vergeer M., Hermans L. (2013). Campaigning on Twitter: Microblogging and online social networking as campaign tools in the 2010 general elections in the Netherlands. Journal of Computer-Mediated Communication, 18, 4: 399. DOI: 10.1111/jcc4.12023.

Vergeer M., Hermans L., Sams S. (2011). Is the voter only a tweet away? Micro-blogging during the 2009 European Parliament election campaign in the Netherlands. First Monday, 16, 8. DOI: 10.5210/fm.v16i8.3540.

Vergeer M., Hermans L., Sams S. (2013). Online social networks and micro-blogging in political campaigning: The exploration of a new campaign tool and a new campaign style. Party Politics, 19, 3: 477. DOI: 10.1177/1354068811407580.

Verweij P. (2012). Twitter links between politicians and journalists. Journalism Practice, 6, 5-6: 680. DOI: 10.1080/17512786.2012.667272.

Voerman G., Boogers M. (2008). Netherlands: digital campaigning in the 2002 and 2003 parliamentary elections. In S. Ward, D. Owen, R. Davies, D. Terras, eds., Making a difference: A Comparative View of the Role of the Internet in Election Politics. Lanham, Boulder, New York: Lexington Books.

Waisbord S., Amado A. (2017). Populist communication by digital means: presidential Twitter in Latin America. Information, Communication \& Society, 20, 9: 1330. DOI: 10.1080/1369118X.2017.1328521.

Wallsten K. (2010). “Yes we can”: How online viewership, blog discussion, campaign statements, and mainstream media coverage produced a viral video phenomenon. Journal of Information Technology \& Politics, 7, 2-3: 163. DOI: 10.1080/19331681003749030.

Wayne Xu, W., Sang Y., Blasiola S., Park H.W. (2014). Predicting Opinion Leaders in Twitter Activism Networks. The Case of the Wisconsin Recall Election. American Behavioral Scientist, 58, 10: 1278. DOI: 10.1177/0002764214527091.

Wells Ch., Thorson, K. (2017). Combining Big Data and Survey Techniques to Model Effects of Political Content Flows in Facebook. Social Science Computer Review archive, 35, 1: 33. DOI: 10.1177/0894439315609528. 
Rivista Trimestrale di Scienza dell'Amministrazione - http://www.rtsa.eu - ISSN 0391-190X ISSNe 1972-4942

Willnat L., Min Y. (2016). The Emergence of Social Media Politics in South Korea: The Case of the 2012 Presidential Election. In Bruns A., Enli G., Skogerbø E., Larsson A.O., Christensen Ch., eds., The Routledge Companion to Social Media and Politics. New York: Routledge.

Xenos M.A., Macafee T., Pole A. (2015). Understanding variations in user response to social media campaigns: A study of Facebook posts in the 2010 US elections. New Media \& Society, 19, 6, 2017: 826. DOI: 10.1177/1461444815616617.

Zappavigna M. (2011). Ambient affiliation: A linguistic perspective on Twitter. New Media \& Society, 13, 5: 788. DOI: 10.1177/1461444810385097. 